DOI: $10.19195 / 0080-3626.62 .10$

KATARZYNA JAMROZIK, JAKUB MACIEJ ŁUBOCKI

\title{
TEORETYCZNE ASPEKTY TWORZENIA ELEMENTÓW DOKUMENTACYJNYCH (ZE SZCZEGÓLNYM UWZGLĘDNIENIEM ABSTRAKTÓW) A ICH RZECZYWISTY KSZTAŁT. PROPOZYCJA BADAŃ W OBSZARZE ARTYKUŁÓW Z CZASOPISM Z ZAKRESU BIBLIOLOGII
}

\begin{abstract}
Współczesne znaczenie informacji i problemy z tym związane. Abstrakty, streszczenia, analizy dokumentacyjne, słowa kluczowe jako próba ich rozwiązania. Współczesne obserwacje i zalecenia dotyczące elementów dokumentacyjnych (praktyka) na tle dotychczasowych zaleceń teoretycznych. Próba typologii elementów dokumentacyjnych. Propozycja badań funkcjonowania elementów dokumentacyjnych w artykułach czasopism z zakresu bibliologii.
\end{abstract}

SŁOWA KLUCZOWE: analizy dokumentacyjne, abstrakty, abstrakty strukturalne, mglistość tekstu

\section{WPROWADZENIE: WZROST ROLI INFORMACJI WE WSPÓŁCZESNYM SPOŁECZEŃSTWIE I WYZWANIA Z TYM ZWIĄZANE}

W przeżywającym rozkwit społeczeństwie informacyjnym, będącym kolejną formacją kształtującą cywilizację, dostęp do informacji jest czynnikiem kluczo$w \mathrm{ym}^{1}$. Mimo swojej niematerialnej postaci traktowana jest ona jak towar, który stanowi podstawę budowania nie tylko wiedzy (co jest zasadniczą funkcją informacji), lecz także dorobku materialnego - dochodu. Społeczeństwo informacyjne to takie, które „,nie tylko posiada rozwinięte środki przetwarzania informacji i komunikowania, lecz środki te są podstawą tworzenia dochodu narodowego i dostarczają źródła utrzymania większości społeczeństwa"2. Jednocześnie dostęp do

${ }^{1}$ Autorzy składają podziękowania dr. Tomaszowi Piekotowi za wskazówki metodyczne i bibliograficzne przy prowadzeniu badań.

2 T. Goban-Klas, P. Sienkiewicz, Społeczeństwo informacyjne. Szanse, zagrożenia, wyzwania, Kraków 1999, s. 53. 
właściwej informacji jeszcze nigdy nie był tak trudny: nowoczesne technologie umożliwiają nam błyskawiczne tworzenie nowych zasobów oraz dostęp do starych, wcześniej nieosiągalnych, co powoduje ich ogromną nadprodukcję i rozproszenie skutkujące nadmiarem możliwości wyszukiwawczych i szumem informacyjnym $^{3}$. To oddala zasoby od poszukującego ich użytkownika informacji.

Co więcej, demokratyzacja procesu publikowania i rozpowszechniania informacji rozluźniła sito oceny jej jakości i obecnie to po stronie użytkownika leży trud wyselekcjonowania informacji wartościowej z oceanu informacji wszelakiej — również błahej, błędnej lub niekompetentnej (wcześniej czynność ta należała bardziej do domeny organizatorów informacji: wydawców, edytorów, bibliotekarzy, bibliografów itp.). „Ciągły wzrost ilości nie zawsze aktualnej, pełnej i wiarygodnej dla człowieka informacji sprawia, że niezbędnym staje się racjonalny proces jej oceny i selekcji'”. Z tych powodów już w latach 70 . XX wieku wyodrębnił się samodzielny kierunek badawczy — ekologia informacji ${ }^{5}$ — odkrywający i badający prawa przepływu informacji w systemach, których elementami są także człowiek i społeczeństwo. Wczesne naukowe ukonstytuowanie się tego zagadnienia nie powinno dziwić: już w 1961 roku Derek John de Solla Price opublikował w zbiorze naukoznawczych esejów komunikat ${ }^{6}$ ze swoich spostrzeżeń dotyczących rozwoju ilościowego nauki. Na podstawie obserwacji rozwoju liczby czasopism naukowych stwierdził, że od roku $1665^{7}$ jej przyrost postępował ze stałą regularnością określaną w matematyce mianem prawa wzrostu wykładniczego, które zakłada, że wraz z postępem czasu w równych jego odstępach liczba obiektów w zbiorze ulegnie pomnożeniu o stały czynnik — ,im większa jakaś rzecz, tym szybszy jest jej wzrost"8 — pisze D. de Solla Price. Zauważył także istotną kwestię: około 1830 roku osiągnięto punkt absurdalny — czasopisma (w owym czasie D. de Solla Price doliczył się ich 300), które powstały przede wszystkim w celu umożliwienia zapoznania się z wszystkimi ukazującymi się książkami i artykułami poprzez odnotowywanie tychże, rozrosły i pomnożyły się tak bardzo, że żaden naukowiec nie był w stanie zapoznać się z nimi wszystkimi. W związ$\mathrm{ku} \mathrm{z}$ tym narodził się pewien wyspecjalizowany typ czasopisma - czasopismo

${ }^{3}$ Ryszard Tadeusiewicz obrazowo dzieli szum informacyjny na smog informacyjny (nadmiar informacji powstający ubocznie podczas jej rozpowszechniania, gromadzenia i opracowywania) i mgłę informacyjną (informacja rozproszona i nieustrukturyzowana) — idem, Społeczność internetu, Warszawa 2002.

${ }^{4}$ W. Babik, Ekologia informacji - wyzwanie XXI wieku, „Praktyka i Teoria Informacji Naukowej i Technicznej" 10, 2002, z. 1 (37), s. 20.

5 Zob. idem, Ekologia informacji, Kraków 2014.

${ }^{6}$ D.J. de Solla Price, Science since Babylon, New Haven 1961 [wyd. polskie: idem, Węzlowe problemy historii nauki, Warszawa 1965, s. 94-121].

7 Pierwsze naukowe czasopismo - ,Journal des Sçavans” — powstało 5 stycznia 1665 roku we Francji; wydarzenie to uznawane jest za początek nowoczesnej nauki.

8 D.J. de Solla Price, Mała nauka - wielka nauka, Warszawa 1967, s. 14. 
przeglądowe (ang. abstract journal) ${ }^{9}$ zawierające zbiory abstraktów. Abstrakty pojawiły się na początku XIX wieku, aby ułatwić zapoznawanie się z nowymi tekstami i ocenianie ich przydatności do własnych badan ${ }^{10}$. Niestety i one w krótkim czasie zaczęły mnożyć się wykładniczo, gdyż referując zawartość czasopism, były od nich niewolniczo uzależnione i jak w soczewce odzwierciedlały ich stan ilościowy, toteż około 1950 roku także osiągnęły ową krytyczną liczbę 300. Warto w tym miejscu podać za D. de Solla Price'em, że wówczas uczeni rozważali nieco groteskową możliwość stworzenia czasopism kolejnego stopnia: przeglądu czasopism przeglądowych.

Myśli z tego eseju D. de Solla Price rozwinął kilka lat później w epokowym dziele Little science - big science ${ }^{11}$, w którym ustanowił „,fundamentalną zasadę wszelkiej analizy nauki”, gdyż prawo to sprawdzało się empirycznie bardzo dokładnie w dostatecznie długich okresach branych pod uwagę. Zasada ta zakłada wykładniczy wzrost składników nauki ${ }^{12}$, możliwych do statystycznego przeanalizowania. Ewentualne odchylenia krzywej wykładniczej wynikają z czynników zewnętrznych (na przykład zahamowanie przyrostu w trakcie obu wojen światowych), po których ustaniu wraca ona do wykładniczego kształtu, jedynie przesunięta względem osi czasu ${ }^{13}$. Oczywiście żadna wielkość w przyrodzie nie może rosnąć w nieskończoność, toteż zasada ta zakłada również, że wzrost rzeczywisty w pewnym momencie (na skutek zbliżenia się do granicy nasycenia) przekształci

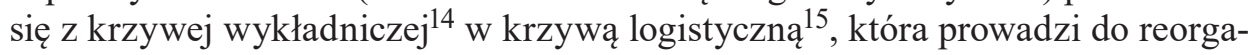

9 Idem, Węzłowe..., s. 99. Pierwszym nowoczesnym czasopismem abstraktowym był „Pharmaceutisches Centralblatt”, a data jego założenia potwierdza hipotezę D.J. de Solla Price'a — czasopismo to powstało dokładnie w 1830 roku.

${ }^{10}$ Ibidem, s. 73.

11 Idem, Little science — big science, New York 1963 [wyd. polskie: idem, Mała nauka...].

12 Składniki te mogą być najprzeróżniejsze: uniwersytety, ważne odkrycia, wybitni fizycy, znane pierwiastki chemiczne, hasła w narodowych słownikach biograficznych, absolwenci wyższych uczelni, czasopisma naukowe, członkowie instytutów naukowych, rozmiar literatury o geometrii nieeuklidesowej itp. — idem, Mała nauka ..., s. 14-15.

13 Ibidem, s. 25.

14 Krzywa wykładnicza to krzywa będąca wykresem funkcji wykładniczej, to jest „funkcji postaci $f(x)=a^{\mathrm{x}}$, gdzie podstawa $a>0$ oraz $a \neq 1$ " - Wielka encyklopedia PWN, t. 30, pod red. J. Wojnowskiego, Warszawa 2005, s. 92. Graficzne wyobrażenie tej funkcji stanowi krzywa podobna do litery J. W przypadku wzrostu wykładniczego zmienna rośnie wykładniczo w czasie, a nie napotykając ograniczeń środowiskowych, dąży do nieskończoności, czego obrazem jest krzywa zbliżająca się do linii pionowej, lecz jej nieosiągająca.

${ }^{15}$ Krzywa logistyczna to „krzywa będąca wykresem funkcji postaci $f(x)=\mathrm{a} \div\left(1+b e^{-\mathrm{cx}}\right)$; przy odpowiednim unormowaniu (wyborze dodatnich stałych $a, b, c)$ stanowi dystrybuantę logistycznego rozkładu prawdopodobieństwa" - Wielka encyklopedia PWN, t. 16, pod red. J. Wojnowskiego, Warszawa 2003, s. 113. Funkcja taka jest podstawą rozkładu logistycznego, który służy do opisu procesów wzrostu osiągających stan wysycenia z powodu ograniczeń środowiskowych. Innymi słowy, graficzne wyobrażenie krzywej logistycznej w postaci dystrybuanty przedstawia sytuację, w której pewien czynnik, obserwowany w upływie czasu, w pierwszej części osiąga 
nizacji, fluktuacji lub zaniku mierzonej wartości ${ }^{16}$. Wynika to choćby z oczywistego faktu, że gdyby składnik nauki, jakim przykładowo jest liczba uczonych, rósł nieskończenie w sposób wykładniczy, osiągnęlibyśmy w pewnym momencie liczbę naukowców większą aniżeli populacja ludzka w ogóle.

Ostatecznie D. de Solla Price podaje, że od 1665 roku liczba czasopism i czasopism przeglądowych (a więc i abstraktów) podwaja się co 15 lat, a to pośrednio odzwierciedla lawinowy przyrost tworzonych informacji. Liczba abstraktów publikowanych na przestrzeni dziejów pokazuje, jak dawno za istotne uznano zwięzłe referowanie treści artykułu, aby pomóc przyszłemu użytkownikowi tekstu w jego właściwej ocenie i ewentualnym wyborze, a więc uznaniu za przydatny. Pokazuje również, jak doniosłą wartość dla naukometrii w ogóle mają te elementy ${ }^{17}$. Oprócz możliwości ilościowych tkwią w nich także możliwości jakościowe: powstają już prace, które bez sięgania do tekstów oryginalnych opierają się na treści wyłącznie elementu dokumentacyjnego ${ }^{18}$. Abstrahując od etyczności takiego postępowania oraz jakości tego typu „rekonstrukcji” (w skrajnym przypadku prowadzi ono do przekonania, że tworzenie linearnego tekstu jest stratą czasu, ponieważ użytkownik może poprzestać na poziomie abstraktu, który w teorii jest soczewką samego tekstu, skupiającą to, co najważniejsze; oczywiście nie trzeba uzasadniać, jak bardzo krótkowzroczna jest to praktyka, choć pojawiają się także opinie przeciwne ${ }^{19}$ ), należy podkreślić, że świadczy ono o tym, jak istotne jest wyposażanie tekstu w sprawne elementy dokumentacyjne, gdyż niejednokrotnie może to stanowić o jego „być albo nie być”.

wzrost taki sam, jak w funkcji wykładniczej, jednak w drugiej części traci impet — krzywa wypłaszcza się aż do osiągnięcia wartości maksymalnej, po której już nie przyrasta, gdyż czynnik wysycił całkowicie obserwowaną przestrzeń. Tym samym krzywa taka ma kształt zbliżony do litery S.

16 D.J. de Solla Price, Mała nauka..., s. 27-36.

17 Celowo nie wprowadza się na tym etapie sformułowania ,abstrakt”, „streszczenie” itp., aby nie sugerować tylko jednego z kilku dokumentacyjnych gatunków piśmienniczych, lecz przedstawić ich ogół.

18 Przykładowo: J. Bielecka-Prus, A. Horolets, Rekonstrukcja praktyk analizy dyskursu na podstawie wybranych anglojęzycznych czasopism dyskursywnych, „Przegląd Socjologii Jakościowej” 9, 2013, z. 1, s. 152-185, o czym autorki informują już na wstępie — „Artykuł jest rodzajem eksperymentu, w którym postanowiłyśmy przeanalizować zawartość abstraktów czasopism anglojęzycznych z zakresu analizy dyskursu w celu zrekonstruowania praktyk analizy dyskursu" (s. 153).

19 „Praktyki te zresztą zyskują legitymizację i wychodzą z szarej strefy — stają się po prostu jedną z deklarowanych i całkiem skutecznych strategii badawczych” — T. Piekot, G. Zarzeczny, Jak napisać efektywny abstrakt? Część pierwsza, „Przegląd Uniwersytecki” 20, 2014, z. 2 (203), s. 31. 
Z tego wynika, że wszelkiego rodzaju adnotacje, abstrakty, ekstrakty i streszczenia mają istotną wartość dla rozwoju nauki i nie od dziśs ${ }^{20}$ są postrzegane jako remedium na nadmiar informacji, jej rozproszenie, nieuporządkowanie i możliwą nieadekwatność lub niską jakość. Toteż ich badanie i ulepszanie powinno być przedmiotem zainteresowania naukowców — w tym bibliologów, szczególnie że to właśnie w tej dyscyplinie wykształciła się metodyka tworzenia takich elementów i do dziś jest ona regulowana przez ten obszar ${ }^{21}$. Nim jednak przejdziemy do zasadniczej części badań, pokazującej, jak sami bibliolodzy stosują się do wytycznych, które propagują, sprawdźmy ogólnie, co o tworzeniu i strukturze takich tekstów mówi teoria, a następnie jak przejawia się ona w obowiązujących obecnie zaleceniach.

\section{TEORETYCZNE ASPEKTY TWORZENIA ELEMENTÓW DOKUMENTACYJNYCH TEKSTU: JĘZYK, STRUKTURA, WARTOŚĆ POZNAWCZA}

„Dobrze przygotowany abstrakt może być najważniejszym punktem w twoim artykule. Musi być treściwy w informacje, ale również czytelny, dobrze zorganizowany, zwięzły i samowystarczalny"22. Trudno o lepszą charakterystykę gatunkową dobrego abstraktu — najpopularniejszego dziś elementu dokumentacyjnego dołączanego do tekstu. Z kolei Polska Norma najlepiej ujmuje cel, jakiemu służy tworzenie wszelkiego rodzaju elementów dokumentacyjnych: ,ułatwienie użytkownikowi dokonania wyboru dokumentu do bezpośredniej lektury spośród innych, przedstawiających dla niego mniejszą wartość lub wzbudzających mniejsze zainteresowanie" 23 . Zalet elementów dokumentacyjnych nie da się przecenić: są łatwo dostępne (nawet gdy pełny tekst jest zablokowany ze względu na miejsce przechowywania lub wymóg wykupienia dostępu, widoczna jest jego reprezenta-

20 Pierwsze metateksty (teksty o tekstach) spotykamy już w bibliotekach Mezopotamii z II tys. p.n.e. Więcej na temat historii i rozwoju abstraktów zob. B. Sosińska-Kalata, Abstrakt, [hasło w:] Encyklopedia książki, t. 1, pod red. A. Żbikowskiej-Migoń, M. Skalskiej-Zlat, Wrocław 2017, s. 141.

${ }^{21}$ Co odzwierciedla się w umiejscowieniu prac normalizacyjnych nad tego typu tekstami: w Polsce normami z zakresu analiz dokumentacyjnych zajmuje się Komitet Techniczny 242 ds. Informacji i Dokumentacji Polskiego Komitetu Normalizacyjnego. Na poziomie międzynarodowym prace te wykonuje Komitet Techniczny 46 Informacja i dokumentacja Międzynarodowej Organizacji Normalizacyjnej (ang. Technical Committee 46 Information and documentation International Organization for Standardization).

22 Publication Manual of the American Psychological Association, wyd. 5, Washington 2001, s. 12. Tłum. - JMŁ, oryg.: „A well-prepared abstract can be the most important paragraph in your article... The abstract needs to be dense with information but also readable, well organized, brief and self-contained".

23 Polska Norma PN-N-01221:1977 Adnotacje i analizy dokumentacyjne, Przedmowa. 
cja dokumentacyjna, często wręcz zwielokrotniona w różnych miejscach, dogodniejszych dla użytkownika i najczęściej bezpłatnych; co więcej, istnieją osobne czasopisma i bazy kolekcjonujące takie elementy) i masowe (obecnie są powszechnie stosowane), co sprawia, że można mówić o wirusowości ${ }^{24}$ elementów dokumentacyjnych - przede wszystkim abstraktów.

Oznacza to, że sposób, w jaki przedstawiamy własne badania w np. abstrakcie, jest najważniejszym czynnikiem, który sprawia, że czytelnik pójdzie dalej — tj. sięgnie do naszego artykułu i być może go zacytuje. Masowy dostęp do abstraktów przez Internet wywołuje zresztą efekt uboczny - nadmiar informacji naukowych (ang. information overload), których badacze ze względu na krótki cykl badawczy nie są w stanie dokładnie przetworzyć25 ${ }^{25}$.

W ten sposób abstrakty są jednocześnie lekarstwem na szum informacyjny i zarazem jego źródłem.

Jak jednak uczynić abstrakt wirusowym? Tomasz Piekot i Grzegorz Zarzeczny opublikowali serię artykułów na ten temat ${ }^{26}$, przyjmując za podstawę swoich teorii to, że „dominujący dziś model uprawiania nauki zakłada, że artykuły naukowe znajdują się w Internecie"27, a skoro Internet jest w dużej mierze medium społecznościowym, to nie można umniejszyć znaczenia tego, że przekazy w mediach społecznościowych rozprzestrzeniają się nie tylko z powodu ich treści (zawartości), lecz także tego, jak są napisane. W związku z tym autorzy zwracają uwagę na trzy cechy, którymi powinien się charakteryzować abstrakt o znamionach wirusowości:

— atrakcyjność percepcyjna, a więc niski poziom mglisto ści (lub à rebours wysoki poziom „odczyt ności”"28);

${ }^{24}$ Wirusowość (ang. virality) rozumie się jako szybkie i masowe rozprzestrzenianie się informacji w środowisku sieciowym dzięki ich multiplikowaniu. W przypadku elementów dokumentacyjnych można ją badać poprzez: liczbę wyświetleń tekstu, liczbę pobrań tekstu, liczbę dodań tekstu do zakładek, a pośrednio także poprzez liczbę cytowań tekstu zasadniczego (za: T. Piekot, G. Zarzeczny, op. cit., s. 31).

25 Ibidem.

26 Ibidem, s. 31-33; T. Piekot, G. Zarzeczny, Jak zwiększyć efektywność abstraktu za pomoca kilku kropek, „Przegląd Uniwersytecki” 20, 2014, z. 4 (205), s. 30-32; iidem, Jak napisać efektywny abstrakt - efektywna kompozycja, „Przegląd Uniwersytecki” 21, 2015, z. 2 (207), s. 31-34.

27 T. Piekot, G. Zarzeczny, Jak napisać... Czéść pierwsza, s. 31.

28 „Odczytność” to propozycja terminologiczna zasugerowana przez dra Tomasza Piekota dla angielskiego terminu readability, która zdaniem autorów niniejszego tekstu jest propozycją słuszną i wartą rozpowszechnienia. Do tej pory w Polsce dość przewrotnie readability określa się jako „mglistość (tekstu)”, w związku z czym w Polsce dąży się do zmniejszania stopnia tego zjawiska, a przecież w pierwotnym założeniu chodziło o zwiększanie tego stopnia. Stąd propozycja, aby i w Polsce zwiększać odczytność, a nie zmniejszać mglistość. Różnica drobna, a jednak istotna. Można spotkać się również z określeniem „czytelność” tekstu, jednak w opinii autorów niniejszego tekstu zbyt mocno kojarzy się ona z technicznymi aspektami tekstu (stopień pisma, krój pisma, tło tekstu, jakość druku, rozdzielczość ekranu itp.), a więc z tym, co w języku angielskim określa się jako legibility, która sprowadza się do procesu odróżniania pojedynczego znaku pisma i stopnia łatwości zidentyfikowania go. Ponadto legibility zawiera się w readability 
- atrakcyjność strukturalna, a więc wysoki stopień logicznego uporządkowania (by jego odbiorca z łatwością odkrywał myśl przewodnią);

— atrakcyjność kognitywna, czyli właściwe zastosowanie strategii kognitywnych.

\subsection{ODCZYTNOŚĆ ABSTRAKTU}

Zapewnienie wysokiego poziomu odczytności sprawia, że użytkownik abstraktu nie napotka bariery na poziomie konstrukcji językowych. Znaczenie ma przede wszystkim stosunek długości zdań do długości (a więc trudności) wyrazów (która w pewnym stopniu wpływa na trudność tekstu) mierzony przy pomocy indeksu FOG ${ }^{29}$. Już w 1997 roku z badań Alana Wheatley’a i C.J. Armstronga wynikało, że najdłuższe abstrakty pochodzą z tekstów prymarnie drukowanych i są najmniej odczytne, najkrótsze abstrakty pochodzą z zasobów internetowych i mają największą odczytność, natomiast obie grupy w zakresie treści wyjaśniają głównie tytuł i najczęściej są wiernym powtórzeniem pierwszych akapitów ${ }^{30}$. Wcześniejsze badania empiryczne wykazały również, że abstrakty są w istotny sposób mniej przystępne od tekstu źródłowego (ale nie przekraczają progu możliwości czytelników) ${ }^{31}$.

jako jeden z czynników wpływających na odczytność, w związku z czym zjawiska te nie powinny być określane za pomocą tego samego terminu.

29 Indeks FOG (z ang. fog 'mgła') mierzy odczytność tekstu i określa stopień jego przystępności (łatwości zrozumienia) dla odbiorcy. Jest obliczany na podstawie statystyki słów i zdań w stosunku do tzw. długich słów tekstu (w języku polskim uznaje się za takie słowa 4-sylabowe i dłuższe), a jego końcowa wartość arytmetyczna ma odniesienie do liczby lat edukacji, które odbiorca musi poświęcić, aby zrozumieć tekst. W podstawowej formie wzór na obliczenie indeksu FOG przedstawia równanie: $\mathrm{FOG}=0,4 *$ ([liczba słów $\div$ liczba zdań] $+100 *$ [liczba słów długich $\div$ liczba słów]). Został opracowany dla języka angielskiego w latach 50. XX wieku przez Roberta Gunninga (opublikowany w: idem, The Technique of Clear Writing, New York 1952), a następnie przystosowany do właściwości innych języków, w tym polskiego. Nie jest to oczywiście jedyny sposób na zmierzenie odczytności tekstu, na przykład na gruncie polskim podobny sposób opracował w latach 60. XX wieku Walery Pisarek (opublikowany w: idem, Jak mierzyć zrozumiałość tekstu?, „Zeszyty Prasoznawcze” 10, 1969, nr 4, s. 35-48). Szerzej na temat innych metod (między innymi Rudolfa Flescha i Petera Kincaida lub Edgara Dale'a i Jeanne Chall) zob. Jasnopis, czyli mierzenie zrozumiałości polskich tekstów użytkowych, pod red. W. Gruszczyńskiego, M. Ogrodniczuka, Warszawa 2015, s. 11-38.

30 A. Wheatley, C.J. Armstrong, A survey of the content and characteristics of electronic abstracts, [s. 1.] 1997, http://www.ukoln.ac.uk/services/elib/papers/supporting/pdf/abstracts.pdf [dostęp: 17.10.2018] lub http://citeseerx.ist.psu.edu/viewdoc/download?doi=10.1.1.95.4018\&rep=re p1\&type=pdf [dostęp: 16.01.2019] (zwłaszcza s. 55-57). Od czasu opublikowania tych badań zaszły ogromne zmiany w komunikacji naukowej: czasopisma elektroniczne upowszechniły się, rozwinął się także ruch Open Access, co nie pozostało bez wpływu na dalsze przemiany w komunikacji realizowanej za pomocą abstraktów.

31 G.B. Dronberger, G.T. Kowitz, Abstract readability as a factor in information systems, „Journal of the American Society for Information Science” 26, 1975, z. 2, s. 108-111; R. King, 
Dzieje się tak prawdopodobnie z powodu silnej kondensacji treści. Autorzy — tworząc abstrakty - wybierają po prostu najważniejsze słowa kluczowe (czyli trudne terminy) i umieszczają je w rozbudowanych zdaniach. Kondensacja abstraktu jest więc zjawiskiem niepożądanym z punktu widzenia jego efektywności (wirusowości) ${ }^{32}$.

W związku z tym dobry abstrakt powinien cechować się niższym indeksem FOG niż tekst zasadniczy, przy czym ze względu na istotną rolę komunikacyjną, jaką spełnia właściwa i ścisła terminologia, obniżanie tego indeksu powinno przebiegać raczej dzięki skracaniu zdań niż stosowaniu krótszych wyrazów.

\subsection{UPORZĄDKOWANIE ABSTRAKTU}

W dobrze skomponowanym abstrakcie użytkownik jest prowadzony przez autora tekstu przez kolejne elementy procesu badawczego. Gdy są one logicznie powiązane i ich następstwo jest oczywiste, użytkownik nie musi trudzić się rekonstrukcją przebiegu badań, gdyż jest on jasno wyłożony. Służą temu między innymi podział na akapity oraz stosowanie nagłówków, spotykane w nowym typie abstraktów - strukturalnych. Wyrosły one na gruncie czasopism medycznych w połowie lat 80 . XX wieku ${ }^{33}$, następnie zastosowano je w czasopismach z innych dziedzin ścisłych, a obecnie spotyka się także w czasopismach humanistycznych (w Polsce przykładem są abstrakty z „Zagadnień Informacji Naukowej”). Z cytowanych ustaleń T. Piekota, G. Zarzecznego czy Jamesa Hartleya wynika, że takie abstrakty:

1. wspierają przetwarzanie informacji (skracają czas i poprawiają jakość procesu);

2. zmuszają autorów do precyzyjnego wyrażania myśli;

3. bezwzględnie obnażają słabości ich procesu badawczego (w takim abstrakcie trudno ukryć rzeczywisty brak celu badań lub nieumiejętność wyciągania wniosków);

4. zawierają więcej informacji (wymuszają uwzględnienie danych faktograficznych);

5. ułatwiają proces recenzowania (choć pojawia się ryzyko recenzowania abstraktu, a nie właściwego tekstu zasadniczego).

Badania empiryczne, polegające na nadaniu struktury abstraktom, które pierwotnie były napisane jednolitym tekstem ciągłym, a następnie porównaniu obu wersji, dowiodły, że choć abstrakty ustrukturyzowane są dłuższe, to jednak cechują się większą czytelnością i zrozumiałością przekazu; sami autorzy pier-

A comparison of the readability of abstracts with their source documents, ,Journal of the American Society for Information Science" 27, 1976, z. 2, s. 118-121.

32 T. Piekot, G. Zarzeczny, Jak zwiększyć..., s. 31.

33 J. Hartley, Current findings from research on structured abstracts, ,Journal of the Medical Library Association" 92, 2004, z. 3, s. 368. Tu dalsze informacje i wnioski z analizy badań przeprowadzanych nad współczesnym abstraktem strukturalnym. 
wotnie nieustrukturyzowanych abstraktów uznali ich ustrukturyzowane wersje za znacznie jaśniejsze ${ }^{34}$. Nie jest to zaskoczenie, gdyż

tradycyjna kompozycja abstraktu przynosi kilka problemów:

1. Samodzielne odkrywanie struktury przez czytelnika oznacza dodatkowy wysiłek i czas na przeprowadzenie tej interpretacji. Jej efekty mogą się zresztą znacznie różnić u poszczególnych czytelników. Subiektywne i dyskusyjne może być zarówno wydzielanie typów sekcji, a nawet granic pomiędzy nimi.

2. Czytelnicy poszukujący konkretnych informacji (np. metodologii lub wyników) nie znajdą ich od razu - muszą przeczytać cały tekst jak wszyscy inni odbiorcy.

3. Abstrakty podobnych artykułów, a nawet abstrakty z tego samego numeru czasopisma mogą się znacznie różnić pod względem autorskiej, subiektywnej struktury ${ }^{35}$.

Te wszystkie niedogodności nie występują, jeśli autor abstraktu wyręczy użytkownika i poda mu informacje w formie uporządkowanej, niewymagającej interpretacji i rekonstrukcji. Nadanie jednolitej struktury oraz wypełnienie jej odpowiednimi danymi sprawi także, że abstrakty będą porównywalne między sobą, co otwiera nowe możliwości metodologiczne w badaniach. Ważną zaletą jest również to, że użytkownik po odszukaniu takiego abstraktu potrzebuje znacznie mniej czasu na podjęcie decyzji o sięgnięciu do pełnego artykułu. Jednak zarazem

przeniesienie tych zasad kompozycyjnych [z praktyki menadżerów korporacyjnych — przyp. aut.] do komunikacji naukowej poważnie zmieniłoby praktyki redagowania abstraktów. Co więcej, istota tej metody jest dla nauki niebezpieczna, o ile nie szkodliwa. Abstrakt korporacyjny przekazuje bowiem czytelnikowi treści tekstu bez konieczności jego lektury ${ }^{36}$.

Mimo tych obaw środowisko naukowe obecnie jednomyślnie uznaje tę formę abstraktu za właściwą dla współczesnego tekstu naukowego w języku angielskim — powszechnym języku nauki naszych czasów - i abstrakty strukturalne są zalecane na poziomie międzynarodowym poprzez Wskazówki EASE (Europejskiego Stowarzyszenia Redaktorów Naukowych) dla autorów i tlumaczy artykutów naukowych publikowanych w języku angielskim. Zalecenia te trzeba przytoczyć w obszerniejszym fragmencie, dobrze bowiem ilustrują, jak w teorii skomponować wirusowy abstrakt i jakie relacje powinny zachodzić między nim a tekstem zasadniczym:

Abstrakt pokrótce wyjaśnia, dlaczego przeprowadzono badania (tło, na jakie pytanie (lub pytania) szukano odpowiedzi (cele), w jaki sposób przeprowadzono badania (metodyka), co stwierdzono (w y n i ki: najważniejsze dane, zależności) oraz jak to zinterpretowano i jakie wyciągnięto wnioski z przeprowadzonych badań (wnioski). Abstrakt musi odzwierciedlać zawartość artykułu, gdyż dla większości czytelników jest on głównym źródłem informacji o przeprowadzonych badaniach. Należy użyć wszystkich słów kluczowych wewnątrz abstraktu, aby ułatwić w przyszłości odnalezienie tego artykułu przez osoby zainteresowane. Wiele internetowych baz

34 J. Hartley, Improving the clarity of journal abstracts in psychology. The case for structure, „Science Communication” 24, 2003, z. 3, s. 366-379.

35 T. Piekot, G. Zarzeczny, Jak napisać... efektywna kompozycja, s. 32.

36 Ibidem, s. 33. 
danych gromadzi bowiem tylko tytuły i abstrakty. W publikacji oryginalnej (czyli artykule przedstawiającym wcześniej niepublikowane wyniki badań) stosuje się abstrakt informujący [oryg. „,informative abstract”; w polskiej terminologii: analiza omawiająca — przyp. aut.], zawierający konkretne wyniki ${ }^{[37]}$. Tylko w artykułach przeglądowych, meta-analizach oraz innych artykułach o szerokiej tematyce stosuje się abstrakty opisowe [oryg. ,indicative abstract”; w polskiej terminologii: analiza wskazująca - przyp. aut.], tzn. wymieniające najważniejsze poruszane tematy, bez konkretnych wyników. W abstrakcie nie zamieszcza się odnośników do tabel i rycin, gdyż abstrakty są publikowane także w oderwaniu od artykułu. Nie zezwala się też na cytowanie literatury w abstrakcie (chyba że jest to absolutnie konieczne, ale wtedy trzeba w nawiasie podać szczegółowe informacje: autora, tytuł, rok itd.). Należy sprawdzić, czy wszystkie informacje zawarte w abstrakcie pojawiają się także w głównej części artykułu ${ }^{38}$.

\subsection{WARTOŚĆ POZNAWCZA ABSTRAKTU}

Ostatnim elementem jest zastosowanie trafnej strategii kognitywnej, tak aby abstrakt nie tworzył bariery poznawczej oraz aby stosował przyjazne dla użytkownika warianty gramatyczne i semantyczne. Jak piszą T. Piekot i G. Zarzeczny, jest to

najtrudniejsze wyzwanie dla autorów abstraktów. W przeciwieństwie do dwóch poprzednich czynników, mamy tu bardzo dużo sprzecznych rozwiązań - brakuje też badań nad tego typu technikami oddziaływania. Najbardziej podstawowe kwestie do rozstrzygnięcia to:

1. Napisać abstrakt o tekście czy o badaniach (por. Celem tekstu było... / Celem badań było...)?

2. Używać narracji pierwszoosobowej czy pisać bezosobowo (por. W tekście omawiam... I W tekście omówiono wyniki badań...)?

3. Jakiego czasu gramatycznego używać w abstrakcie (por. Badania obejmowały próbki wód gruntowych z lat... / Badania obejmuja próbki wód gruntowych z lat... / W tekście omówione zostaną badania próbek wód gruntowych z lat...)? ${ }^{39}$.

Zagadnienia te, jak widać, odnoszą się jednoznacznie do stylu języka, jakim się posługujemy, lecz nie chodzi jedynie o bardziej lub mniej naukową odmianę tego stylu, lecz także o jego cechy warunkowane kulturowo. Język tekstów naukowych odzwierciedla przede wszystkim wymogi gatunkowe (w aspektach formalnym, pragmatycznym, poznawczym), które zawsze podlegają szerszemu warunkowaniu kulturowemu (naukowcy stosują różne strategie językowe w różnych kręgach kulturowych, a preferencje te wynikają między innymi z tradycji, którą zastają i którą przesiąkają w procesie włączania się do społeczności akademickiej). W związku z tym na wybór strategii kognitywnej przy pisaniu abstraktu mogą mieć wpływ właśnie owe zależności kulturowe. Problematyka ta, wypływająca jasno w przywołanych przykładach, wprost przynależy do badań dyskursu nauko-

37 Tu odesłanie do Appendix: Abstracts (s. 7), zawierającego szczegółowe omówienie, czym $\mathrm{w}$ istocie są kluczowe elementy abstraktu strukturalnego.

38 EASE Guidelines for authors and translators of scientific articles to be published in English [polska wersja językowa; tłum. S. Ufnalska], 2015, s. 2, http://www.ease.org.uk/sites/default/ files/ease_guidelines-2015-polish.pdf [dostęp: 17.10.2018]; wyróżnienia własne.

39 T. Piekot, G. Zarzeczny, Jak napisać... Część pierwsza, s. 33. 
wego, który można zwięźle zreferować na podstawie wniosków Anny Duszak ${ }^{40}$ oraz Marii Wojtak ${ }^{41}$.

Styl naukowy danego tekstu (w tym abstraktu) jest uwarunkowany kulturowo, dlatego można mówić o swego rodzaju etnoretorykach tego stylu, co umożliwia analizę tekstów w kategoriach danej wspólnoty akademickiej. Dzięki istnieniu etnoretoryk ujawniają się w tekstach naukowych konwencje charakterystyczne dla danej kultury pisanej („duch języka”). Stereotypowo uważa się, że język naukowy jest obiektywny i bezosobowy, co ma wynikać z przedmiotu podlegającego opisowi (jest nim nauka, która powinna być obiektywna i bezstronna, tworzona dla celów wyższych niż prywatny sukces i rozgłos) oraz metodyki tego opisu. W imię prawdy autor powinien pozostać ,niewidoczny”, pozbywać się emocji, subiektywności, spekulacji czy perswazji ${ }^{42}$. Jednak lingwistyka tekstualna dowiodła, że teksty naukowe mimo wszystko są podatne na czynniki spoza przedmiotu (uprzejmość, asertywność, stosunek do posiadanej wiedzy) i nawet najbardziej naukowe teksty nie są wolne od patosu, figur retorycznych i metaforyki. Różne kultury tworzą różne modele komunikacji, a naukowcy mimowolnie przenoszą je do swoich tekstów, dlatego można zaobserwować dwie odmienne praktyki:

a. odpowiedzialność piszącego za właściwy odbiór tekstu (tak zwana jasność ad hominem - tekst przystępny, klarowny, jednoznaczny: odbiorca nie musi go interpretować $\rightarrow$ tekst jest skonwencjonalizowany);

b. odpowiedzialność odbiorcy za właściwy odbiór tekstu (tzw. jasność ad rem - tekst jest mało eksplicytny, z niedomówieniami, pozostawiający swobodę interpretacji $\rightarrow$ tekst jest niepewny komunikacyjnie).

Koncentracja na potrzebach i możliwościach czytelnika (a.) determinuje odpowiedzialność piszącego i tworzy styl dialogowy charakteryzujący się linearnością tekstu. Tekst jest relacyjny, a jego treść schematyczna i uproszczona. Natomiast koncentracja autora na własnym procesie myślowym (b.) determinuje odpowiedzialność odbiorcy i implikuje styl monologowy, charakteryzujący się dygresyjnością tekstu, a jego treść jest celowo intelektualizowana. Oczywiście sytuacje wymienione $w$ punktach a. i b. są ekstremami na kontinuum potrzeb względem odbioru tekstu, ponieważ czytelnik zawsze w jakimś stopniu interpretuje tekst, przy czym to autor pozostawia mu do tego węższy lub szerszy margines. Jednak

40 A. Duszak, Tekst, dyskurs, komunikacja kulturowa, Warszawa 1998, rozdz. 5.2.3 Style intelektualne - interakcyjny charakter tekstów akademickich, s. 275-284; rozdz. 5.3.2. Zróżnicowanie kulturowe w organizacji tekstu akademickiego, s. 288-308.

${ }^{41}$ M. Wojtak, Dyskurs asekuracyjny w dyskursie naukowym, [w:] Dyskurs naukowy — tradycja i zmiana, pod red. S. Gajdy, Opole 1999, s. 139-146.

${ }^{42}$ Co już stoi w sprzeczności z postulatem wirusowości abstraktu, abstrakt taki bowiem musi być perswazyjny - wynika to dobitnie z definicji perswazji: „namawianie do czegoś lub odradzanie czegoś z przytoczeniem odpowiednich argumentów" (Stownik języka polskiego PWN, http://sjp.pwn.pl/sjp/perswazja;2571293 [dostęp: 17.10.2018]). A przecież nadrzędnym celem abstraktu jest namówienie do skorzystania z pełnego artykułu. 
dzięki wskazaniu tych ekstremów można zrozumieć, w jakich dwóch kierunkach to kontinuum się rozciąga, a wybór jednego z nich wskazują konkretne cechy tych ekstremów.

$\mathrm{Z}$ tego wynika, że praktyka a. będzie preferować skoncentrowanie na tekście (Celem tekstu było...), a praktyka b. — na samych badaniach (Celem badań było...). Z kolei wybór narracji oraz czasu gramatycznego może wiązać się z obecnością asekuracji w dyskursie naukowym. Osłonowe strategie komunikacyjne, jak nazywa je M. Wojtak, również wynikają z dążenia do zachowania podstawowych wartości nauki - obiektywizmu, prawdziwości i powtarzalności procesu badawczego. Jednym z wyznaczników formalnych asekuracji w tekście naukowym jest „maskowanie podmiotowej perspektywy przekazu" ${ }^{33}$ polegające na nadawaniu tekstowi maski bezosobowości poprzez:

a. zaimek ,my” + czasownik w 1. osobie liczby mnogiej (jako „my” autorskiej skromności lub „my” inkluzyjne, uwspólniające nadawcę z odbiorcą),

b. zaimek „on" jako, ,ja" + czasownik w 3. osobie liczby pojedynczej,

c. bezosobowe formy czasownikowe.

$\mathrm{Z}$ tego typu powszechnych praktyk może wynikać wybór form $W$ tekście omówiono wyniki badań..., W tekście omówione zostana badania próbek wód gruntowych z lat..., niekoniecznie właściwych w abstrakcie. Tak więc język abstraktu, a tym samym wybór strategii kognitywnej, może wynikać z uwarunkowań kulturowych i stać w sprzeczności z postulatem wirusowości, choć określenie, która ze strategii jest najwłaściwsza, wymaga jeszcze dalszych, precyzyjniejszych badań.

\subsection{DOTYCHCZASOWE ZALECENIA TEORETYCZNE ODNOŚNIE DO TWORZENIA ELEMENTÓW DOKUMENTACYJNYCH}

Nakreślenie najnowszych ustaleń w zakresie tworzenia skutecznego abstraktu prowadzi do konkluzji, że dotychczasowe zalecenia normatywne i deskryptywne opublikowane w wydawnictwach normalizacyjnych i leksykograficznych wymagają natychmiastowej aktualizacji.

Podstawowym dokumentem mającym służyć pomocą w tworzeniu elementów dokumentacyjnych jest Polska Norma PN-N-01221:1977 Adnotacje i analizy dokumentacyjne. Norma ta, stworzona głównie z myślą o różnego rodzaju serwisach i źródłach bibliotecznych, bibliograficznych, dokumentacyjnych i informacyjnych, została - być może zbyt pochopnie - narzucona na całe uniwersum publikowanych dokumentów: ,postanowienia normy należy uwzględniać także przy sporządzaniu adnotacji i analiz dokumentacyjnych drukowanych w dokumentach pierwotnych, na przykład przy opracowywaniu streszczeń autorskich lub

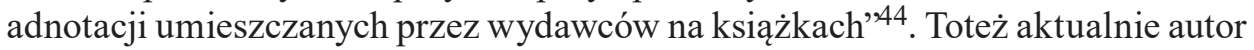

43 M. Wojtak, op. cit., s. 141.

44 Polska Norma PN-N-01221:1977, pkt 1.2. 
tekstu zasadniczego, proszony o wyposażenie tekstu w elementy dokumentacyjne, stoi w rozterce, czy uczynić te elementy skutecznymi, czy też być może mniej skutecznymi, ale zgodnymi z postanowieniami normalizacyjnymi — w jakimś stopniu powszechnymi i zapewniającymi jednolitość opracowanej informacji, niezależnie od jej miejsca i autora. Norma PN-N-01221:1977 formalnie została wycofana przez Polski Komitet Normalizacyjny (PKN) z dniem 18 grudnia 2012 roku, jednak status ten nie przesądza o jej wadliwości lub odrzuceniu (to dotyczy jedynie norm zastąpionych przez nowszą wersję lub inną normę), lecz oznacza jedynie, że nie została ona w okresie ostatnich lat zrewidowana. Jej postanowienia nadal uznaje się za sprawne, choć PKN nie bierze już odpowiedzialności za ich zgodność z aktualnym stanem wiedzy i spójność z systemem normalizacyjnym. W związku z tym de facto norma PN-N-01221:1977 wciąż może być (i jest) powszechnie wykorzystywana.

Norma ta podaje opisy czterech rodzajów adnotacji, trzech rodzajów adnotacji dokumentacyjnych i dwóch rodzajów streszczeń — opisy te posłużyły za podstawę przedstawionej dalej typologii. Zasady opracowania ${ }^{45}$ nakazują ogólnie przedstawienie tematyki dokumentu i jego cech, zwłaszcza czasu i miejsca powstania, autora, poziomu trudności i przeznaczenia czytelniczego, przy jednoczesnym zakazie powtarzania informacji zawartych już w tytule tekstu oryginalnego. Analizy dokumentacyjne, obszerniejsze od adnotacji, dodatkowo powinny uwzględniać informacje o nowatorstwie koncepcji i zastosowaniu praktycznym, a także być pozbawione elementów oceniających, interpretujących czy krytycznych (co jest dopuszczalne, a niekiedy wskazane w przypadku adnotacji). Pojawia się także znane już ze Wskazówek EASE... zalecenie, aby elementy dokumentacyjne były zrozumiałe bez potrzeby sięgania do oryginału tekstu, natomiast w przeciwieństwie do nich dopuszcza się cytowanie dokumentu ${ }^{46}$. Norma zwraca też szczególną uwagę na język - styl powinien być prosty, rzeczowy, jasny, pozbawiony nadmiaru słów i zdań ${ }^{47}$. Ponieważ elementy dokumentacyjne są wyrażone w języku naturalnym, oczywistością jest również, że muszą one „spełniać wszystkie warunki poprawności ortograficznej, gramatycznej, stylistycznej, interpunkcyjnej $\mathrm{i}$ terminologicznej, obowiązujące $\mathrm{w}$ danym języku i danej dziedzinie wiedzy. [...] Wymaga się stosowania wyłącznie standaryzowanych skrótów (np., itp., wg)"48. Zalecany układ graficzny dla wszystkich elementów to jeden akapit (poprzedzony opisem bibliograficznym dokumentu oryginalnego, o ile element nie jest do niego dołączony $)^{49}$.

\footnotetext{
45 Ibidem, pkt 3.2 .

46 Ibidem, pkt 3.3.1.

47 Ibidem, pkt 3.3.2.

48 B. Sosińska-Kalata, op. cit., s. 142.

49 Polska Norma PN-N-01221:1977, pkt 4.
} 
W tym miejscu warto zwrócić uwagę na spór terminologiczny dotyczący jednego z elementów. Polska Norma obok określenia ,analiza dokumentacyjna” w nawiasie dopowiada ,abstrakt”. Podobnie pierwszeństwo analizie dokumentacyjnej przed abstraktem daje większość słowników i encyklopedii bibliologicznych $^{50}$. Tymczasem w powszechnym użyciu w języku polskim jest ,abstrakt” lub (niepoprawnie) ,streszczenie”, natomiast ,analiza dokumentacyjna”, mimo że to jej norma przyznaje pierwszeństwo, pojawia się w codziennym stosowaniu rzadziej (zapewne pod wpływem rozpowszechnienia angielskiego ekwiwalentu: określenie ,abstrakt” pochodzi od angielskiego abstract). Dopiero w najnowszej Encyklopedii ksiażki, na podstawie uzusu językowego, przyznano pierwszeństwo abstraktowi ${ }^{51}$. Wymiennemu stosowaniu określeń ,abstrakt” i „streszczenie” (ang. summary) jednoznacznie sprzeciwia się międzynarodowa norma ISO 214:1976 Documentation - Abstracts for publications and documentation (norma ta była podstawą opracowania polskiej normy PN-N-01221:1977):

Abstrakty nie powinny być mylone z podobnymi acz odrębnymi terminami: adnotacja, ekstrakt i streszczenie. Adnotacja jest krótkim komentarzem lub wyjaśnieniem do dokumentu lub jego zawartości, a nawet bardzo krótkim określeniem, zazwyczaj podawanym jako nota za opisem bibliograficznym dokumentu. Ekstrakt jest jedną lub kilkoma partiami dokumentu wybranymi do reprezentowania całości. Streszczenie jest krótkim ponownym przedstawieniem treści dokumentu w nim samym (zazwyczaj na jego końcu) złożonym z najistotniejszych ustaleń i wniosków, i ma na celu dopełnić zorientowanie czytelnika w tekście, który studiował. (Ponieważ pozostałe elementy dokumentu, jak cel, metodologia, nie są zazwyczaj zawierane w streszczeniu, termin ten nie powinien być traktowany jak synonim abstraktu, co oznacza, że abstrakt, tak jak zdefiniowano go powyżej, nie powinien być nazywany streszczeniem, a streszczenie, jeśli jest zastosowane, nie powinno powtarzać — nie w pełnym zakresie - abstraktu) ${ }^{52}$.

50 Encyklopedia wiedzy o książce, pod red. A. Birkenmajera, B. Kocowskiego, J. Trzynadlowskiego, Wrocław 1971, szp. 49: [Abstrakt, zob. Analizy dokumentacyjne] $\rightarrow$ „Analizy dokumentacyjne, zwane też niekiedy abstraktami (z ang. abstracts), są to adnotacje podające tematykę dokumentów lub główne tezy autorów (A. wskazująca, zwana też adnotacją wskazującą), bądź podające najważniejsze wnioski lub także argumenty autorów (A. omawiająca lub streszczenie dokumentacyjne, zwane również adnotacją omawiającą). A.d. są stosowane w pracach ośrodków dokumentacji i informacji”. Słownik encyklopedyczny informacji, języków i systemów informacyjno-wyszukiwawczych, oprac. B. Bojar, Warszawa 2002, s. 20: [Abstrakt, zob. Analiza dokumentacyjna $\rightarrow$ „metainformacja o treści dokumentu, zwykle będąca tekstem języka naturalnego, stanowiąca streszczenie dokumentu dokonane zgodnie z kryteriami przyjętymi w danym systemie informacyjno-wyszukiwawczym, towarzyszące opisowi bibliograficznemu lub bezpośrednio dokumentowi”. Podręczny słownik bibliotekarza, oprac. G. Czapnik, Z. Gruszka przy współpr. H. Tadeusiewicz, Warszawa 2011, s. 19: [Abstrakt, zob. Analiza dokumentacyjna] $\rightarrow$ „Analiza dokumentacyjna, abstrakt. Adnotacja treściowa towarzysząca opisowi bibliograficznemu lub bezpośrednio tekstowi dokumentu. a. abstract; f. analyse; n. Abstraktum".

51 Encyklopedia książki, t. 1, s. 153: [hasła: Analiza deskryptorowa; Analiza dokumentacyjna; Analiza omawiajaca; Analiza wskazująca, zob. Abstrakt] $\rightarrow$ „Abstrakt (analiza dokumentacyjna) - to zwięzłe streszczenie tekstu pierwotnego. Jego celem jest ułatwienie czytelnikowi szybkiej orientacji w zawartej w tekście treści" (s. 141).

52 ISO 214:1976 Documentation - Abstracts for publications and documentation, pkt 2. Tłum. - JMŁ, oryg.: „Abstracts should not be confused with related, but distinct, terms: anno- 
Zauważmy również, że sens znaczeniowy określenia „streszczenie” wymaga, aby utwór w formie streszczenia respektował układ wywodu oryginalnej treści ${ }^{53}$. Tymczasem elementy dokumentacyjne nie powinny być stale powiązane $\mathrm{z}$ tą właściwością, gdyż w niektórych sytuacjach warto na potrzeby użytkownika informacji posługującego się elementem pierwotną treść przedstawić w zmienionym układzie, na przykład poprzez jej grupowanie według innego klucza niż w oryginale, co może korzystnie wpłynąć na komunikatywność elementu.

\section{RODZAJE ELEMENTÓW DOKUMENTACYJNYCH}

Na podstawie cytowanych zaleceń można sporządzić ogólną typizację elementów dokumentacyjnych tekstu, będącą częściowo rewizją postanowień normy PN-N-01221:1977. Podstawową cechą elementu jest jego autorstwo. W związku z tym można wyróżnić elementy pochodzenia odautorskiego (jako autora elementu rozumie się nie tylko autora tekstu zasadniczego, lecz także jego redaktora i edytora, czyli wszystkie osoby odpowiedzialne za formę i treść tekstu zasadniczego, do którego element jest dołączony) lub pochodzenia odbibliog raficznego, jeśli element jest tworzony w procesie dokumentacyjnym, a więc nie jest dołączony do tekstu zasadniczego ${ }^{54}$. Element odautorski niewątpliwie będzie lepiej

tation, extract, and summary. An annotation is a brief comment or explanation about a document or its contents, or even a very brief description, usually added as a note after the bibliographic citation of the document. An extract is one or more portions of a document selected to represent the whole. A summary, if one is needed, is a brief restatement within the document (usually at the end) of its salient findings and conclusions, and is intended to complete the orientation of a reader who has studied the preceding text. (Because other portions of the document, for example purpose, methodology, are not usually condensed into this type of summary, the term should not be used synonymously with «abstract»; i.e. abstract as defined above should not be called a summary, and a summary, if used, should not duplicate - should not take on the full scope of - the abstract.)". W podobnym duchu wypowiada się amerykańska norma ANSI/NISO Z39.14-1997 (R2009) Guidelines for Abstracts, pkt 3.

53 Według normy PN-ISO 5127:2005 Informacja i dokumentacja. Terminologia streszczenie to „reprezentacja dokumentu respektująca układ jego wywodu” (pkt 4.2.2.2.05).

$54 \mathrm{Na}$ ważkość kwestii autorstwa i faktu dołączenia elementu dokumentacyjnego do tekstu oryginalnego wskazywał już kilkanaście lat temu Stefan J. Niementowski (idem, Propozycja zmian w PN-77/N-01221 Adnotacje $i$ analizy dokumentacyjne. Artykut dyskusyjny, „Normalizacja” 60, 1992, z. 6, s. 32-33), który w 1992 roku proponował uwypuklenie aspektu współopublikowania elementu wraz z tekstem oryginalnym. W związku z tym słusznie postulował on - w miejsce kontrowersyjnego terminu „streszczenie autorskie” — wyróżnienie a nalizy współopublikowanej, to jest takiej, która jest ogłoszona razem z tekstem, którego dotyczy. Kwestię autorstwa S.J. Niementowski skrupulatnie rozgraniczył: jeśli analizę opracował autor dokumentu pierwotnego, ma być to analiza ws półopublikowana autorska, natomiast jeśli była opracowana przez innego uczestnika procesu wydawniczego - analiza współopublikowana redakcyjna. Jednak tak głębokie wniknięcie w genezę autorstwa nie wydaje się konieczne, szczególnie że kompetencje autora i redakcji niekiedy przenikają się tak dalece, że trudno czasem wskazać, od kogo 
odwzorowywał informację zawartą w tekście oryginalnym - osoba zewnętrznie analizująca tekst zazwyczaj nie osiąga takiego poziomu znawstwa tematu, jakim może poszczycić się autor tekstu: to autor wie najlepiej, o czym pisał i jak to ująć. Jednocześnie jednak element przygotowywany zewnętrznie zazwyczaj jest tworzony na potrzeby jakiegoś systemu i wówczas pracownik informacji, mimo że zwykle gorzej zna temat publikacji, lepiej zna system informacyjny (oraz jego użytkowników i ich potrzeby), dla którego element jest tworzony. Można także, na podstawie spostrzeżenia T. Piekota i G. Zarzecznego (,efektywny abstrakt nie jest tekstem o tekście (artykule), lecz tekstem o badaniach"55), przyjąć, że elementy odautorskie są w pierwszej kolejności tekstami o badaniach (gdyż o nich przede wszystkim chce poinformować autor tekstu — o tym, że napisał tekst informuje już opis bibliograficzny), natomiast elementy odbibliograficzne, tworzone przez pracownika informacji z myślą o dopełnieniu informacji o tekście wynikającej z opisu bibliograficznego, są głównie tekstami o artykułach, choć oczywiście tekst o artykule też jest tekstem o badaniach, jednak w sposób wtórny.

Można wskazać także kryterium celu, w jakim został stworzony element. Od celu bowiem będzie uzależniony dobór informacji i budowa elementu. W związku z tym można wyróżnić elementy o celu in formacyjnym (element pozwala zorientować się w zasadniczej treści tekstu oryginalnego), indykatywnym (element wskazuje na istnienie dokumentu i jego główne tezy zawarte w tekście oryginalnym), streszczającym (element zastępuje oryginalny tekst z powodu jego trudnej dostępności). Niektóre źródła ${ }^{56}$ wskazują jeszcze jeden cel - zgłoszeniowy (element obszernie prezentuje treść planowaną do przedstawienia na konferencji lub wykonania w ramach jakiegoś projektu w celu jej oceny, a następnie jej odrzucenia lub zaakceptowania do dalszego etapu postępowania) — jednak takie elementy najbardziej odbiegają od typowych elementów dokumentacyjnych, często zawierają cytaty i bibliografię załącznikową, a przede wszystkim nie stanowią reprezentacji tekstu już istniejącego, lecz dopiero mającego powstać, w związku z czym w ogóle trudno je uznać za element dokumentacyjny.

Przechodząc do szczegółowego omówienia rodzajów elementów dokumentacyjnych, należy podkreślić, że można wskazać kilka ich podstawowych odmian.

1. Adnota cja jest zwięzłą (może mieścić się w jednym zdaniu lub nawet tylko jego fragmencie) charakterystyką dokumentu wyrażoną w języku naturalnym, która nie wynika ze standardowych elementów identyfikacyjnych tekstów, a jest niezbędna ze względu na niedostatki tych elementów lub ich zbytnią ogólność: „,stosuje się wówczas, gdy zachodzi potrzeba poinformowania użytkownika informacji o cechach relewantnych dokumentu innych niż te, które podaje opis bibliograficzny

swoją genezę i kształt ostateczny czerpie dany element opublikowanego dzieła. Bezspornie jednak należy wyróżnić, czy element dokumentacyjny pochodzi od zespołu autorsko-redakcyjnego, czy też od zewnętrznego uczestnika procesu wymiany informacji.

55 T. Piekot, G. Zarzeczny, Jak zwiększyć..., s. 30.

56 Encyklopedia książki, t. 1., s. 142. 


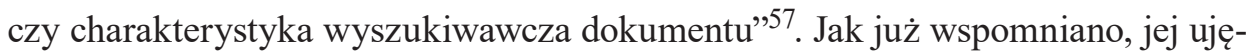
cie, ze względu na cel objaśnienia, wskazania czy doprecyzowania treści lub formy dokumentu, pozwala na zawarcie elementów krytycznych, interpretacyjnych czy wartościujących jego treść lub cechy formalne. Może być wyjaśn iając a (doprecyzowuje niejednoznaczny tytuł lub tytuł o znaczeniu przenośnym), zawartościowa (odwzorowuje lub dosłownie podaje spis treści lub jego fragment, najczęściej w wypadku prac o rozbudowanej strukturze), księgoznawcza (dotyczy cech formalnych dokumentu, a więc podaje informacje ważne z punktu widzenia bibliologii, na przykład: opisuje cechy typograficzne, rodzaj druku, papieru, oprawy, historię danego egzemplarza, rozwiązuje wątpliwości związane $\mathrm{z}$ autorstwem lub proweniencją, podaje przeznaczenie czytelnicze, wskazuje związki bibliograficzne z innymi dokumentami w postaci na przykład polemik czy recenzji), zalecająca (zachęca do lektury i/lub ułatwia interpretację tekstu, porusza problemy treści bez ujawniania samej fabuły, uzasadnia wartość treści dokumentu i opisuje poziom jego opracowania; często łączy się z adnotacją księgoznawczą, gdyż może wskazywać przeznaczenie czytelnicze). Oprócz tego można wskazać jeszcze jeden rodzaj adnotacji, którego nie zna norma PN-N-01221:1977, a który jest stosowany w praktyce ${ }^{58}$. Chodzi o adnotację ilościow ą, która znajduje zastosowanie głównie w bibliografiach bibliografii i podaje objętość jakiegoś spisu bibliograficznego poprzez liczbę jego pozycji. Można także wyobrazić sobie tego rodzaju adnotację do innych typów dokumentów, np. słowników czy encyklopedii, wyrażającą wówczas informację o liczbie artykułów hasłowych. Zatem jej istotą jest scharakteryzowanie dokumentu (wydawnictwa informacyjnego) poprzez liczbę zawartych w nim jednostek.

2. Analiza dokumentacyjna (powszechnie dziś nazywana abstraktem) jest informacją o treści dokumentu wyrażoną w języku naturalnym; stosowana w celu szerszego poinformowania użytkownika informacji o treści lub formie dokumentu niż czynią to opis bibliograficzny, charakterystyka wyszukiwawcza dokumentu i adnotacja. Bezwzględnie musi spełniać warunek obiektywnego odwzorowania informacji, a więc jest pozbawiona elementów krytycznych, interpretacyjnych czy wartościujących. Może być wskazująca (podaje tematykę dokumentu i/lub zawarte w nim główne tezy; jej celem jest zasygnalizowanie istnienia dokumentu, a nie odwzorowanie jego treści ${ }^{59}$ ) lub omawiająca (dodatkowo przedstawia szczegółową problematykę, cele i tezy, dane faktograficzne, zastosowane metody i wywiedzione wnioski wraz z ich uzasadnieniem) ${ }^{60}$. Ist-

57 Stownik encyklopedyczny informacji..., s. 15.

${ }^{58} \mathrm{Na}$ jej istnienie wskazuje: A. Matczuk Adnotacja, [hasło w:] Encyklopedia ksiażki, t. 1, s. 145 .

59 Ibidem, s. 22.

60 PN-ISO 5127:2005 Informacja i dokumentacja. Terminologia stosuje te określenia odwrotnie: analiza wskazująca to „krótki abstrakt dający pojęcie o zawartości i formie dokumentu” (pkt 4.2.2.2.03), zaś analiza omawiająca to „abstrakt dający wyjaśnienie treści dokumentu wystarczające do umożliwienia użytkownikowi zdecydowania, czy czytać pełny tekst, czy nie" 
nieją dwie szczególne odmiany analizy omawiającej. Pierwszą z nich jest analiza strukturalna ${ }^{61}$ (analiza omawiająca, która została podzielona na kolejne akapity z nagłówkami przedstawiającymi kolejne etapy pracy badawczej; najczęściej spotykanymi działami są: cel, metoda, wyniki, wnioski badań, choć listę tę można dowolnie poszerzać w zależności od celu przygotowywania analizy na przykład o takie działy jak: tło, ograniczenia, zastosowanie praktyczne, wartość poznawcza badań czy charakter artykułu i inne). Drugim rodzajem jest analiza streszczająca (element dokumentacyjny charakteryzujący się najwyższym stopniem nasycenia treściowego, analiza omawiająca w pełni uwzględniająca dane faktograficzne, w związku z czym w pewnych sytuacjach może w ogóle zastąpić tekst oryginalny). Do tej pory określana była jako „streszczenie dokumentacyjne”, jednakże, po pierwsze, streszczenie musiałoby wiernie odzwierciedlać oryginalny układ wywodu, co jest wskazane, lecz nie zawsze konieczne przy przygotowywaniu tego rodzaju elementów, po drugie, będąc w istocie odmianą analizy, termin ją określający nie powinien wyłamywać się ze schematu terminologicznego dla tej grupy elementów (wszystkie elementy o cechach analizy powinny być nazywane analizami, a nie w niektórych przypadkach analizami, a w innych streszczeniami) ${ }^{62}$. Ten rodzaj analizy stosowany jest w przypadku bariery językowej (tekst oryginalny w języku obcym) lub bariery dostępności (tekst oryginalny przechowywany w zbiorze trudno dostępnym).

3. Eks trakt różni się od adnotacji i analizy tym, że jest zbudowany wyłącznie ze zdań wyjętych z tekstu pierwotnego ${ }^{63}$. Jest więc czymś w rodzaju obszernego cytatu reprezentującego całość.

4. Streszczenie to ponowne przedstawienie tekstu pierwotnego respektujące oryginalny układ jego wywodu. Dopełnia zorientowanie czytelnika w tekście i składa się z najistotniejszych ustaleń i wniosków w nim zawartych. W przeciwieństwie do analiz nie musi zawierać informacji o celu i metodologii badań. Intuicyjnie streszczenie kojarzy się z tekstami objętościowo znacznie obszerniejszymi niż analizy dokumentacyjne ${ }^{64}$, jednakże nie jest to ich cecha dystynktywna, w przeciwieństwie do wymogu odtwarzania oryginalnego układu wywodu.

Oprócz tego w normie PN-N-01221:1977 znajdują się jeszcze dwa określenia, do których należy odnieść się sceptycznie. Pierwsze z nich to wieloznaczne sformułowanie streszczenie autorskie, które jeśli w ogóle powinno być używane, to jedynie jako określenie zarezerwowane dla takich elementów dokumentacyjnych, które są tworzone przez autora dokumentu oryginalnego i jednocześ-

(pkt 4.2.2.2.04). Ta zamiana nie wydaje się właściwa, dlatego pozostawiono terminologię z normy PN-N-01221:1977.

61 Do tej pory, oprócz Encyklopedii książki (t. 1, s. 142), żaden słownik czy polska norma, łącznie z obszerną PN-ISO 5127:2005, nie odnotowały istnienia abstraktu strukturalnego, choć znała go już norma ANSI/NISO Z39.14-1997 (R2009), pkt 3.

62 S.J. Niementowski, op. cit., s. 34.

63 Encyklopedia książi, t. 1, s. 141.

64 S.J. Niementowski, op. cit., s. 33-34. 
nie respektują oryginalny układ wywodu tego dokumentu. Jednakże streszczenie autorskie i tak musi mieć formę analizy wskazującej lub omawiającej, więc jego wyróżnienie w ogóle nie wydaje się zasadne ${ }^{65}$. Natomiast z niniejszych rozważań należy całkowicie wyłączyć coś, co norma określa jako a nalizę deskry ptorową. W myśl postanowień normy taka analiza jest informacją o treści dokumentu, wyrażoną w języku deskryptorów lub języku słów kluczowych. Jest to błąd logiczny, ponieważ tekst utworzony za pomocą języka deskryptorowego lub języka słów kluczowych to nic innego, jak charakterystyka wyszukiwawcza dokumentu (charakterystyka deskryptorowa lub charakterystyka słowna) ${ }^{66}$, podobna do tej wyrażonej na przykład w języku haseł przedmiotowych czy za pomocą symboli klasyfikacyjnych. Określenie ,,analiza deskryptorowa” błędnie sugeruje więc, że obok takich charakterystyk istnieją jeszcze jakieś dodatkowe teksty stworzone w tych językach, które są analizami deskryptorowymi, co nie jest prawdą ${ }^{67}$.

\section{ZAŁOŻENIA METODOLOGICZNE PROPONOWANYCH BADAŃ}

Na podstawie opisów prezentowanych przez redakcje czasopism wybrano po dwa tytuły wiodących czasopism z zakresu dyscyplin bibliologicznych i przypisano je do subdyscyplin: dla księgoznawstwa były to „Roczniki Biblioteczne”68 oraz „Studia o Książce i Informacji” "69, dla bibliotekoznawstwa - „Przegląd Biblioteczny”70 oraz „Toruńskie Studia Bibliologiczne”71, dla informatologii -

65 Szczegółowe uzasadnienie zob. ibidem, s. 32-33.

66 B. Sosińska-Kalata, op. cit., s. 143.

67 Stownik encyklopedyczny informacji..., s. 20.

68 „»Roczniki Biblioteczne« — ogólnopolskie czasopismo naukowe z zakresu nauki o książce (bibliologii) i bibliotekoznawstwa. Publikuje opracowania dotyczące: teorii i metodologii bibliologii i bibliotekoznawstwa i dziedzin pokrewnych; historii książki i bibliotek w Polsce i w świecie; współczesnego bibliotekarstwa, zwłaszcza w odniesieniu do bibliotek naukowych; kształcenia pracowników książki i bibliotek" [wyróżn. autorów] — Roczniki Biblioteczne. Ogólnopolskie czasopismo naukowe z zakresu nauki o książce i bibliotekoznawstwa, http://rocznikibiblioteczne.ibi.uni.wroc.pl/ [dostęp: 17.10.2018].

69 „Studia o Książce i Informacji zawierają w dużej części artykuły młodych badaczy, poświęcone teorii i praktyce bibliologii. W ostatnich latach uległa poszerzeniu tematyka artykułów, ukierunkowana w znacznej mierze na estetykę książki. Publikowane są monografie artystów książki, typografów, analizowane wypowiedzi teoretyczne dotyczące działalności e dy torskiej" [wyróżn. autorów] — Studia o Książce i Informacji (dawniej: Bibliotekoznawstwo), http://bibl.sjol. eu/ [dostęp: 17.10.2018].

70 „Najstarsze polskie czasopismo bibliotekarskie o charakterze naukowym obejmujące wszystkie podstawowe nurty polskiego bibliotekoznawstwa, księgoznawstwa, bibliografii i informacji naukowej. [...] Jeden z najlepszych periodyków z dziedziny bibliotekoznawstwa w Europie. Zapewnia możliwość publikacji i wymiany poglądów całemu środowisku bibliotekarskiemu oraz ludziom nauki związanym z naszym zawodem" [wyróżn. autorów] — Przegląd Biblioteczny, http://www.sbp.pl/przeglad [dostęp: 17.10.2018].

71 „»Toruńskie Studia Bibliologiczne« (TSB) to czasopismo naukowe dedykowane różnym subdyscyplinom bibliologii. [...] Wśród preferowanej problematyki znajdują się czytelnictwo 
„Zagadnienia Informacji Naukowej”72 oraz „Praktyka i Teoria Informacji Naukowej i Technicznej"73. Z każdego tytułu wybrano losowo dwa artykuły. Oczywiście próba złożona z 12 artykułów jest zdecydowanie za mała, by mówić o reprezentatywności badań. Służy ona tylko ilustracji, jak takie badania powinny być przeprowadzone i jakie wyniki można dzięki nim osiągnąć. Docelowo badania powinny być prowadzone na kompletnej próbie w określonych ramach czasowych (patrz: Aneks 2); ciekawe wyniki mogłoby dać rozmieszczenie tych ram w kilku interwałach czasowych, na przykład lata 2013-2014, 2003-2004, 1993-1994, 1983-1984, aby ukazać także przemiany, jakie dokonywały się w czasie.

Wybrane artykuły cechowały się następującymi parametrami:

— ukazały się w latach 2012-2014;

- dotyczyły badanego zakresu (na łamach czasopisma uznanego za na przykład informatologiczne mogły ukazywać się artykuły z zakresu na przykład księgoznawstwa —wybierano tylko artykuły zgodne z zakresem);

— miały charakter oryginalny lub co najmniej problemowy (wykluczano zatem artykuły o mniejszej wartości, sygnalne, wstępne);

— były wyposażone w jakiekolwiek elementy dokumentacyjne (niezależnie od tego, czy były one nazwane prawidłowo lub w ogóle nazwane), między innymi streszczenia, analizy, adnotacje, słowa kluczowe, deskryptory itd.

Po wyselekcjonowaniu adekwatnych artykułów stworzono bazę (patrz: Aneks nr 1) zawierającą:

a. opis bibliograficzny artykułu;

b. wskazanie języka artykułu wraz z jego wartością FOG Hasłowego oraz liczbą słów;

c. wynotowanie wszystkich elementów dokumentacyjnych, w które wyposażony został artykuł, w kolejności występowania oraz pod taką nazwą, pod jaką występował w tekście, wraz z oznaczeniem języka;

książki i prasy; polityka wydawnicza i ruch wydawniczo-księgarski; prasoznawstwo; elektroniczne zasoby informacyjne; współczesne bibliotekarstwo i biblioterapia; nowoczesne technologie przetwarzania, przechowywania i prezentacji informacji; wykorzystanie technologii informacyjno-komunikacyjnych do tworzenia zasobów informacyjnych" [wyróżn. autorów] — O TSB, http:// www.home.umk.pl/ tsb/?q=pl/ [dostęp: 16.01.2016].

72 „Głównym celem niniejszego czasopisma jest zapewnienie forum dla rozpowszechniania artykułów naukowych i wyników badań z zakresu nauki o informacji (informatologii) oraz innych dyscyplin, w których podejmowane są analizy społecznych i technologicznych aspektów działalności informacyjnej prowadzonej w różnych sferach współczesnego życia społecznego" [wyróżn. autorów] — Zagadnienia Informacji Naukowej - Studia Informacyjne, http://www.sbp. $\mathrm{pl} /$ artykul/?cid=2885\&prev=497 [dostęp: 17.10.2018].

73 „Od 1993 roku Polskie Towarzystwo Informacji Naukowej wydaje kwartalnik naukowy pt. «Praktyka i Teoria Informacji Naukowej i Technicznej», który jest czasopismem obejmującym swym zakresem dziedzinę informacji naukowej (i n formatologii) i obszarów pokrewnych [wyróżn. autorów] - Praktyka i Teoria Informacji Naukowej i Technicznej, http://www.ptin.org.pl/ ptint.html [dostęp: 17.10.2018]. 
d. do tych elementów, które były brane pod uwagę (porównywano jedynie te elementy, które były stworzone w języku tekstu zasadniczego, ponieważ, przykładowo, porównywanie angielskiego tekstu z polskim abstraktem mogłoby prowadzić do wypaczeń w wynikach ze względu na odmienne właściwości tych języków), podano wartość FOG Hasłowego oraz liczbę słów (w przypadku tych elementów dokumentacyjnych, które są pisane tekstem ciągłym) i/lub liczbę elementów (w przypadku tych elementów dokumentacyjnych, które są składane z określeń semantycznych niepowiązanych gramatyką);

e. przytoczenie in extenso elementów dokumentacyjnych branych pod uwagę (patrz pkt d.).

Wartość FOG Hasłowego obliczano przy pomocy aplikacji Jasnopis ${ }^{74}$. Pozostałe dane i wartości badacze ustalali samodzielnie. Na podstawie tak opracowanych danych można było przejść do ich analizy i wysnuwania wniosków.

\section{PRÓBKA REALIZACJI BADAŃ. WNIOSKI}

Na podstawie przedstawionych założeń teoretycznych i metodycznych przeanalizowano losową próbę 12 artykułów. Oczywiście wniosków wysuwanych na podstawie tak skromnej próby nie można uznać za wiążące, a jedynie za hipotezy warte dalszych badań i weryfikacji. Niemniej już taka mała próba może wykazać jakieś zależności. Sprawdzono zatem:

a. stosunek FOG Hasłowego artykułu do FOG Hasłowego elementu (co pozwala zbadać, czy zgodnie z zaleceniami treść elementu jest odczytniejsza, a więc łatwiej przyswajalna, od treści artykułu);

b. liczbę słów elementu i stosunek tej liczby do liczby słów tekstu zasadniczego (co pozwala zbadać aktualną tendencję objętościową, która wedle zaleceń powinna się zwiększyć; objętość jest również podawana w zaleceniach normalizacyjnych);

74 Jasnopis, http://jasnopis.pl/aplikacja [dostęp: 17.10.2018]. Aplikacja ta powstała jako odpowiedź na potrzebę szybkiego diagnozowania stopnia odczytności tekstu — zob. W. Gruszczyński et al., W poszukiwaniu metody automatycznego mierzenia zrozumiałości tekstów informacyjnych, „Poradnik Językowy” 2015, nr 2, s. 9-22. Szczegółowe omówienie algorytmu stosowanego w tej aplikacji podano w: Ł. Dębowski, Analiza statystyczna trudności tekstu, http://jasnopis.pl/static/ pdf/seminarium2-jak-wylicza.pdf [dostęp: 17.10.2018]; natomiast jej genezę i podstawy metodologiczne opisano w: W. Gruszczyński, Jak powstawat Jasnopis, http://www.jasnopis.pl/static/pdf/ seminarium2-jak-powstawal.pdf [dostęp: 19.12.2018]. Zob. też. Jasnopis czyli mierzenie zrozumiałości... Nie jest to oczywiście jedyna tego rodzaju aplikacja, jej wybór został podyktowany tym, że jest ona najbardziej zaawansowana, oparta na bogatej i unikalnej podstawie naukowej i metodologicznej, oferuje różne możliwości (oprócz obliczania indeksu FOG w kilku odmianach mierzy statystykę i wskaźniki kilkunastu innych parametrów tekstu) i jednocześnie jest powszechnie dostępna. 
c. stopień wykorzystania słów kluczowych w treści elementu (co pozwala zbadać, czy zgodnie z zaleceniami w elemencie zastosowano wszystkie słowa kluczowe celem jego łatwiejszej indeksacji w bazach — przejętemu elementowi nie muszą towarzyszyć słowa kluczowe dołączone do tekstu oryginalnego); ze względu na ograniczenia techniczne brano pod uwagę tylko słowa kluczowe dołączone przez autorów do tekstu zasadniczego, choć bardziej wiarygodne wyniki uzyskano by, jeśli słowa kluczowe określano by na podstawie analizy tekstu zasadniczego przez badaczy — autorzy tekstu zasadniczego mogli słowa kluczowe dobrać niesłusznie lub (jak w dwóch przypadkach) w ogóle nie dołączyć ich do tego tekstu;

d. poprawność nazewnictwa elementów względem zaleceń normalizacyjnych (co pozwala zbadać, czy istniejące zalecenia terminologiczne wytrzymują konfrontację z uzusem językowym).

Szczegółowe konfrontacje danych przedstawia tabela 1.

Tab. 1. Szczegółowe dane wyliczone lub przejęte z artykułów (patrz: Aneks nr 1) (5 $^{75}$

\begin{tabular}{|c|c|c|c|c|c|c|c|c|c|c|}
\hline & $\mathrm{A}$ & B & $\mathrm{C}$ & $\mathrm{D}$ & $\mathrm{E}$ & $\mathrm{F}$ & $\mathrm{G}$ & $\mathrm{H}$ & I & $\mathrm{J}$ \\
\hline Lp. & 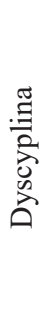 & 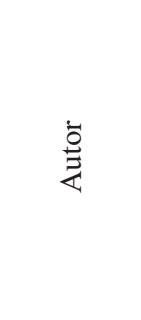 & 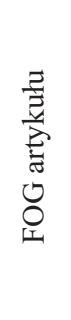 & 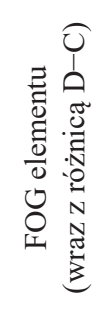 & 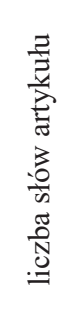 & 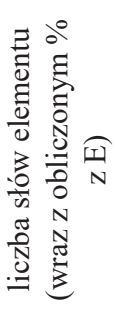 & 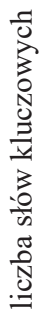 & 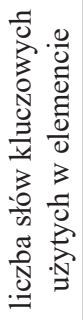 & 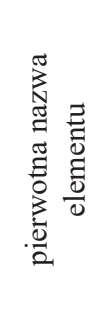 & 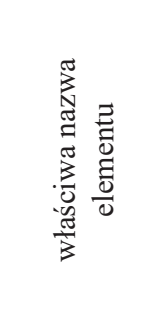 \\
\hline 1 & & $\begin{array}{c}\text { Nwa- } \\
\text { chukwu, } \\
\text { Obaseki }\end{array}$ & 7,08 & $\begin{array}{c}8,01 \\
(+0,93)\end{array}$ & 2345 & $\begin{array}{c}240 \\
(10,23)\end{array}$ & 8 & 6 & abstract & $\begin{array}{c}\text { (structured) } \\
\text { abstract }\end{array}$ \\
\hline 2 & 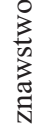 & Zybert & 8,19 & $\begin{array}{c}9,46 \\
(+1,27)\end{array}$ & 5494 & $\begin{array}{c}78 \\
(1,41)\end{array}$ & 4 & 3 & abstrakt & $\begin{array}{c}\text { analiza } \\
\text { (abstrakt) } \\
\text { strukturalna }\end{array}$ \\
\hline 3 & $\begin{array}{l}\frac{0}{0} \\
\frac{0}{0} \\
\frac{0}{0} \\
0\end{array}$ & Imańska & 6,57 & $\begin{array}{c}12,69 \\
(+6,12)\end{array}$ & 3156 & $\begin{array}{c}137 \\
(4,34)\end{array}$ & 5 & 4 & $\begin{array}{l}\text { stresz- } \\
\text { czenie }\end{array}$ & $\begin{array}{c}\text { analiza } \\
\text { (abstrakt) } \\
\text { omawiająca }\end{array}$ \\
\hline 4 & & Ciszewska & 8,85 & $\begin{array}{c}16,65 \\
(+7,8)\end{array}$ & 1635 & $\begin{array}{c}122 \\
(7,46)\end{array}$ & 4 & 3 & $\begin{array}{l}\text { stresz- } \\
\text { czenie }\end{array}$ & $\begin{array}{c}\text { analiza } \\
\text { (abstrakt) } \\
\text { omawiająca }\end{array}$ \\
\hline
\end{tabular}

75 Pozycje 7-8 miały dołączone elementy w języku innym niż język tekstu zasadniczego (zob. poz. 5. i 10. Aneksu nr 1), więc większość wartości nie mogła być wyliczona. 


\begin{tabular}{|c|c|c|c|c|c|c|c|c|c|c|}
\hline 5 & \multirow{4}{*}{ 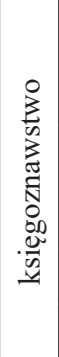 } & Ossowski & 10,25 & $\begin{array}{c}6,23 \\
(-4,02)\end{array}$ & 15704 & $\begin{array}{c}25 \\
(0,16)\end{array}$ & 4 & 0 & $\begin{array}{c}\text { [brak } \\
\text { określe- } \\
\text { nia] }\end{array}$ & $\begin{array}{c}\text { analiza } \\
\text { (abstrakt) } \\
\text { wskazująca }\end{array}$ \\
\hline 6 & & Wagner & 11,53 & $\begin{array}{c}9,78 \\
(-1,75)\end{array}$ & 11441 & $\begin{array}{c}33 \\
(0,29)\end{array}$ & 12 & 2 & $\begin{array}{c}\text { [brak } \\
\text { określe- } \\
\text { nia] }\end{array}$ & $\begin{array}{c}\text { analiza } \\
\text { (abstrakt) } \\
\text { wskazująca }\end{array}$ \\
\hline 7 & & Setkowicz & 14,26 & $*$ & 3761 & $*$ & * & $*$ & summary & Summary \\
\hline 8 & & Łamasz & 11,05 & $*$ & 5677 & * & * & $*$ & summary & Summary \\
\hline 9 & \multirow{4}{*}{$\begin{array}{l}\cdot \frac{\pi}{60} \\
0 \\
0 \\
0 \\
\tilde{\Xi} \\
0 \\
0 \\
. \Xi\end{array}$} & Kamińska & 12,49 & $\begin{array}{c}15,84 \\
(+3,35)\end{array}$ & 3960 & $\begin{array}{c}231 \\
(5,82)\end{array}$ & 8 & 2 & abstrakt & $\begin{array}{c}\text { analiza } \\
\text { (abstrakt) } \\
\text { strukturalna }\end{array}$ \\
\hline 10 & & Nahotko & 13,31 & $\begin{array}{c}16,8 \\
(+3,49)\end{array}$ & 4033 & $\begin{array}{c}228 \\
(5,65)\end{array}$ & 6 & 6 & abstrakt & $\begin{array}{c}\text { analiza } \\
\text { (abstrakt) } \\
\text { strukturalna }\end{array}$ \\
\hline 11 & & $\begin{array}{l}\text { Michalska, } \\
\text { Myśliwska }\end{array}$ & 15,52 & $\begin{array}{c}18,11 \\
(+2,59)\end{array}$ & 2476 & $\begin{array}{c}180 \\
(7,26)\end{array}$ & 0 & - & $\begin{array}{c}\text { [brak } \\
\text { określe- } \\
\text { nia] }\end{array}$ & $\begin{array}{c}\text { analiza } \\
\text { (abstrakt) } \\
\text { omawiająca }\end{array}$ \\
\hline 12 & & Dziak & 13,58 & $\begin{array}{c}11,74 \\
(-1,84)\end{array}$ & 2567 & $\begin{array}{c}130 \\
(5,05)\end{array}$ & 0 & - & $\begin{array}{c}\text { [brak } \\
\text { określe- } \\
\text { nia] }\end{array}$ & $\begin{array}{c}\text { analiza } \\
\text { (abstrakt) } \\
\text { omawiająca }\end{array}$ \\
\hline
\end{tabular}

Źródło: opracowanie własne.

Na podstawie tabeli 1 można zaobserwować, że:

1. Wartość FOG jest istotnie różna w obrębie badanych subdyscyplin: wartości dla artykułów bibliotekoznawczych (mieszczące się w przedziale od 6,57 do 8,85; średnia arytmetyczna: 7,67) są niższe od wartości dla artykułów księgoznawczych (od 10,25 do 11,53; średnia arytmetyczna: 10,89), a te z kolei są niższe od wartości dla artykułów informatologicznych (od 12,49 do 15,52; średnia arytmetyczna: 13,73). Takie wyniki można interpretować bogatą i skomplikowaną terminologią księgoznawstwa oraz posiłkowaniem się przez informatologię metodami nauk ścisłych. Współczynnik FOG jest tak skonstruowany, aby odpowiadać poziomom edukacji (latom poświęconym na edukację), które trzeba osiągnąć do zrozumienia tekstu. Stąd wynika, że teksty bibliotekoznawcze są zrozumiałe na poziomie pierwszej klasy gimnazjum, teksty księgoznawcze — u końca pierwszej klasy liceum, natomiast teksty informatologiczne — na pierwszym roku studiów; są to wartości zaskakująco niskie, jak na polskie teksty naukowe ${ }^{76}$ i wynika z nich,

76 Odczytność tekstów naukowych w języku polskim jest zróżnicowana także ze względu na dyscyplinę, której dotyczą, i waha się od 15,2 punktów FOG w architekturze (3. rok studiów), przez 16,6 w lingwistyce (4. rok studiów), do 18,4 w naukach prawnych (1. rok studiów doktoranckich) - według badań prowadzonych na tekstach naukowych z pięciu dyscyplin, zreferowanych w: T. Piekot, G. Zarzeczny, Jak zwiększyć..., s. 30, wykres nr 1, oprac. M. Maziarz. 
że bibliologia ze średnią wartością FOG tekstów naukowych na poziomie 10,76 jest nauką operującą językiem właściwym dla pierwszej klasy liceum.

2. Porównanie FOG elementu z FOG artykułu pokazuje, że mimo zaleceń elementy dokumentacyjne do tekstów z zakresu bibliologii wciąż są trudniej przyswajalne niż teksty zasadnicze. W grupie 10 artykułów tylko 3 mają niższą wartość FOG elementu, a w obrębie całej grupy przeciętnie element jest o 1,79 punktów FOG trudniejszy niż tekst zasadniczy. W obrębie dyscyplin nie widać szczególnego zróżnicowania (dobra odczytność elementów księgoznawczych wszystkie wartości porównania są ujemne - jest pozorna, gdyż z czterech próbek tylko dwie nadawały się do wyliczeń [zob. poz. 5 i 10 Aneksu nr 1, które nie nadawały się do szczegółowych obliczeń, ponieważ język elementu był inny niż język tekstu zasadniczego], te zaś były nieporównywalne z innymi wartościami ze względu na specyficzną konstrukcję [zob. poz. 9 i 11 Aneksu nr 1]). Najwyższy zanotowany wynik porównania to $+7,8$ punktów FOG, najniższy: $-4,02$.

3. Polska Norma PN-N-01221:1977 podaje wartości liczbowe opisujące wskazaną objętość niektórych elementów: 100 wyrazów dla analizy wskazującej, 150 dla adnotacji zalecającej i 250 dla analizy omawiającej ${ }^{77}$. Badania wykazały, że jedynie elementy artykułów informatologicznych zbliżają się do podanych wartości - elementy dwóch pozostałych dyscyplin mają rażące niedomiary (31,2\% wypełnienia w elemencie artykułu Zybert [poz. 12 Aneksu 1], a nawet 25\% wypełnienia w elemencie artykułu Ossowskiego [poz. 9 Aneksu 1]). Najbliżej prawidłowej wartości usytuował się element artykułu Nwachukwu i Obaseki [poz. 8 Aneksu 1] z wartością $96 \%$, choć należy pamiętać, że abstrakt strukturalny powinien być jeszcze obszerniejszy (nawet do 300 słów; zwiększenie to wynika już z samej formy zakładającej nagłówki kolejnych akapitów — przykładowo nagłówki w „Zagadnieniach Informacji Naukowej” według zaleceń redakcyjnych liczą 15 słów). Niestety ze względu na szczupłość próby niemożliwe było uchwycenie tendencji w liczbie słów elementów, choć już stan aktualny pokazuje, że jakakolwiek by ona była, obecnie jest za niska w stosunku do zaleceń. Tu, tak jak w punkcie 2 ., również nie da się uchwycić ewentualnej korelacji tych wartości z dziedzinami z uwagi na zaniżenie wartości w obrębie księgoznawstwa (brak połowy próbek).

4. Zaobserwowano także, że przeciętnie liczba słów użytych w elemencie stanowi $4,76 \%$ słów tekstu zasadniczego i wydaje się, że jest to stosunek prawidłowy, choć w związku z postulatem zwiększania objętości abstraktów mógłby być on większy o 1-2 punkty procentowe. Wartość elementu dla artykułu Nwachukwu i Obaseki [poz. 8 Aneksu] - 10,23\% — jest już przesadą, okazuje się bowiem, że ów abstrakt ma objętość ponad 1/10 tekstu zasadniczego.

5. Stopień wykorzystania słów kluczowych również jest zadowalający: 75$80 \%$ dołączonych słów kluczowych pojawiło się w treści elementów dokumen-

77 Polska Norma PN-N-01221:1977, pkt 3.3.10. 
tacyjnych. Niestety, wartości te można przyjąć za prawdopodobne jedynie dla bibliotekoznawstwa, ponieważ tylko połowa artykułów z pozostałych dziedzin została wyposażona w słowa kluczowe.

6. Nazewnictwo, o ile w ogóle występuje (33\% elementów nie była nazwana explicite), jest stosowane poprawnie, choć brakuje mu ścisłości. Powstaje tu jednak pytanie: czy daleko idąca precyzja jest w ogóle konieczna i czy dążenie do niej należy do obowiązków redaktorów? Z satysfakcją należy zatem przyjąć fakt, że nazewnictwo to nie stoi w rażącej sprzeczności z postulowaną terminologią (a pamiętajmy, że ona sama wymaga rewizji na gruncie polskim). Ważne jest to, że kardynalne rozróżnienie na streszczenie (które cechuje szacunek dla struktury oryginalnego tekstu) i analizę/abstrakt (cechowane szczególnym uwypukleniem prezentacji celu i metody badań) jest respektowane przez autorów i redaktorów.

\section{PODSUMOWANIE}

Z przedstawionej próby badań wyłania się raczej pozytywny obraz elementów dokumentacyjnych towarzyszących artykułom z zakresu bibliologii w odniesieniu do wykorzystania słów kluczowych i nazewnictwa. Ich objętość względem tekstu jest także prawidłowa, choć wymaga pewnego zwiększenia, zbyt mała jest jednak wartość bezwzględna tej objętości w stosunku do zaleceń normalizacyjnych. Natomiast praktyka tworzenia tych elementów stoi w całkowitej sprzeczności z aktualnymi zaleceniami dotyczącymi przejrzystości językowej. Z pewnością pogłębionej analizy i weryfikacji wymaga niepokojąca sugestia wyłaniająca się z przedstawionych wyników, że język artykułów bibliologicznych stoi na stosunkowo niskim poziomie względem innych dyscyplin. Propozycję metodologii kontynuacji badań przedstawia Aneks nr 2.

ANEKS NR 1: BAZA DANYCH ZEBRANYCH W TRAKCIE BADAŃ WRAZ Z ILUSTRACJĄ MATERIAŁEM (W UKŁADZIE ALFABETYCZNYM)

1. Wanda A. Ciszewska, Przywilej biblioteczny a prawo do wynagrodzenia za wypożyczenia biblioteczne (public lending right), „Toruńskie Studia Bibliologiczne" 7, $2014 \mathrm{nr} 2$ (13), s. 135-159.

Artykuł w języku polskim FOG Hasłowy 8,85; 1635 słów.

Streszczenie [pol] FOG Hasłowy 16,65; 122 słowa.

Słowa kluczowe [pol] liczba słów kluczowych: 4.

Abstract [eng]

Keywords [eng] 
STRESZCZENIE: Artykuł 28 Ustawy o prawie autorskim i prawach pokrewnych z 4 lutego 1994 r. zezwala instytucjom, takim jak biblioteki, archiwa i szkoły, na nieodpłatne udostępnianie egzemplarzy utworów (tzw. przywilej biblioteczny). Jednak Dyrektywa Rady Wspólnot Europejskich $\mathrm{Nr}$ 92/100 z dnia 19 listopada 1992 r. w sprawie prawa najmu i użyczenia oraz niektórych praw pokrewnych prawu autorskiemu w zakresie własności intelektualnej (wersja ujednolicona: 2006/115/WE) wprowadza konieczność wynagradzania z tytułu publicznego użyczania egzemplarzy utworów chronionych (tzw. public lending right). Na przełomie 2013 i 2014 r. Ministerstwo Kultury i Dziedzictwa Narodowego przeprowadziło szereg konsultacji w ramach Forum Prawa Autorskiego dotyczących nowelizacji prawa autorskiego, w tym przede wszystkim wprowadzenia wynagrodzenia za wypożyczenia biblioteczne. Artykuł przybliża stanowiska organizacji bibliotekarskich i środowiska wydawców w tym zakresie.

SLOWA KLUCZOWE: Forum Prawa Autorskiego, prawo autorskie, przywilej biblioteczny, wynagrodzenia za wypożyczenia biblioteczne.

2. Aleksandra Dziak, Wybrane narzędzia technologii informacyjnej w badaniach humanistycznych, „Praktyka i Teoria Informacji Naukowej i Technicznej” 21, 2013, nr 1-2 (81-82), s. 30-37.

\section{Artykuł w języku polskim FOG Hasłowy 13,58; 2567 słów. [brak określenia] [pol] FOG Hasłowy 11,74; 130 słów. [brak określenia] [eng]}

Technologie informacyjne (TI), których rozwój jest związany bezpośrednio ze zmianami cywilizacyjnymi wpływają na wzrost efektywności działań w zakresie wielu dziedzin, także naukowych. Celem referatu jest omówienie wybranych narzędzi TI, które mogą zostać wykorzystane w procesie badawczym przez współczesnego humanistę. Autorka przedstawi zestaw aplikacji ułatwiających prowadzenie badań w zakresie szeroko rozumianej humanistyki. Na początku zostaną omówione narzędzia, umożliwiające dotarcie do jak największej liczby materiałów źródłowych, na podstawie których badacz może sformułować tezę swoich dociekań. Następnie autorka przedstawi aplikacje, które pozwolą na prowadzenie analiz potrzebnych do udowodnienia postawionej tezy (np. Wordle, ImagePlot). Na końcu zostaną zaprezentowane narzędzia umożliwiające stworzenie internetowej publikacji naukowej oraz jej promocję w świecie cyfrowym. Powyższy przegląd wybranych aplikacji służących do prowadzenia badań humanistycznych pozwoli na sformułowanie wniosku, że ich przydatność jest możliwa do zaobserwowania na każdym etapie badawczym.

3. Iwona Imańska, Biblioteka Jakuba Bliwernitza (1667-1731), burmistrza Malborka, „Toruńskie Studia Bibliologiczne” 6, 2013, nr 2 (11), s. 9-30.

Artykuł w języku polskim FOG Hasłowy 6,57; 3156 słów.

Streszczenie [pol] FOG Hasłowy 12,69; 137 słów.

Słowa kluczowe [pol] liczba słów kluczowych: 5.

Abstract [eng]

Keywords [eng] 
STRESZCZENIE: Żyjący na przełomie wieków XVII i XVIII Jakub Bliwernitz należał do grona dobrze wykształconej elity Malborka. Kilkakrotnie był burmistrzem miasta. Studiował prawo i interesował się historią regionu. Dał się poznać także jako właściciel sporego, bo liczącego około 2 tysięcy tytułów, księgozbioru. Po jego śmierci biblioteka została sprzedana na publicznej aukcji, zorganizowanej w Malborku od 16 lipca 1732 r. Wydrukowany na tę okazję katalog aukcyjny umożliwia zapoznanie się z zawartością biblioteki, która charakterem zbiorów i wielkością nie odbiegała od bibliotek prywatnych gromadzonych w tym samym czasie przez urzędników miejskich większych miast prowincji, takich jak Toruń i Elbląg. W bibliotece Bliwernitza dominowały książki z zakresu prawa i polityki oraz historii, uzupełnione o literaturę religijną, książki z czasów szkolnych i podstawowe dzieła z innych dziedzin wiedzy. Księgozbiór służył burmistrzowi przede wszystkim w wykonywaniu jego obowiązków zawodowych i realizowaniu zainteresowań historycznych.

SŁOWA KLUCZOWE: biblioteki prywatne, Bliwernitz Jakub (1667-1731), księgozbiory historyczne, Malbork, XVII-XVIII w.

4. Anna Kamińska, Wykorzystanie źródeł i narzędzi elektronicznych przez polskich studentów kierunków humanistycznych, „Zagadnienia Informacji Naukowej" 52, 2014, nr 2 (104), s. 149-163.

Artykuł w języku polskim FOG Hasłowy 12,49; 3960 słów.

Abstrakt [pol] FOG Hasłowy 15,84; 231 słowa.

Słowa kluczowe [pol] liczba słów kluczowych: 8.

Abstract [eng]

Keywords [eng]

Abstrakt Cel/teza: Celem artykułu jest charakterystyka zachowań informacyjnych związanych z wykorzystywaniem przez studentów kierunków humanistycznych naukowych źródeł i narzędzi elektronicznych do przygotowania prac magisterskich. Podstawę charakterystyki stanowią wyniki badań przeprowadzonych wśród studentów Uniwersytetu Warszawskiego.

Koncepcja/metody badań: W badaniach, przeprowadzonych od marca do maja 2014 r., wykorzystano podejście jakościowe, stosując technikę wywiadu częściowo ustrukturyzowanego. Treść wywiadów po ich przeprowadzeniu transkrybowano i opracowano za pomocą programu do analizy danych jakościowych Welf QDA. Do analizy zebranego materiału wykorzystano technikę kodowania znaczenia. Próbę badawczą stanowiła grupa 14 studentów drugiego roku studiów magisterskich: 7 magistrantów polonistyki i 7 magistrantów historii.

Wyniki i wnioski: Analiza danych zgromadzonych na podstawie wywiadów pokazała, że respondenci używali źródeł elektronicznych w momencie, gdy dostęp do materiałów w formie tradycyjnej był utrudniony, elektroniczne narzędzia wykorzystywali zaś do wyszukiwania konkretnych publikacji w wersji papierowej lub elektronicznej. Najpopularniejszymi okazały się biblioteki cyfrowe, wyszukiwarka internetowa Google oraz elektroniczne katalogi bibliotek. Stwierdzono niewielką znajomość wśród studentów takich narzędzi, jak menedżery bibliograficzne i rzadkie z nich korzystanie przy pisaniu prac magisterskich. Mimo ogólnej otwartości studentów na technologie cyfrowe i popieranie przez nich rozwoju naukowych zasobów Open Access, potwierdzone zostało ogólne przekonanie o przywiązaniu humanistów do pracy w środowisku papierowym.

Oryginalność/wartość poznawcza: Przeprowadzone badanie uzupełnia lukę w zakresie badań nad zachowaniami informacyjnymi magistrantów. Jego szczególną wartość stanowi wybór 
grupy badawczej spośród studentów kierunków humanistycznych, którzy do tej pory bardzo rzadko byli obejmowani tego typu badaniami.

Słowa kluczowe: Cyfrowa humanistyka. Cyfrowe zasoby naukowe. Edukacja informacyjna. Elektroniczne źródła naukowe. Elektroniczne narzędzia naukowe. Kompetencje informacyjne. Studenci humanistyki. Zachowanie informacyjne.

5. Aleksandra Łamasz, Relacje między obrazem a tekstem $w$ powojennych ilustrowanych edycjach liryków Juliana Tuwima, „Studia o Książce i Informacji” 2012, nr 31, s. 11-28.

Artykuł w języku polskim FOG Hasłowy 11,05; 5677 słów. Summary [eng]

6. Maria Małgorzata Michalska, Anna Myśliwska, ,Łowcy informacji” internetowej. Ewolucja warsztatu pracownika Zaktadu Informacji Naukowej —od formy tradycyjnej do wyspecjalizowanej informacji cyfrowej, „Praktyka i Teoria Informacji Naukowej i Technicznej” 20, 2012, nr 3-4 (79-80), s. 19-25.

\section{Artykuł w języku polskim FOG Hasłowy 15,52; 2476 słów. [brak określenia] [pol] FOG Hasłowy 18,11; 180 słów. [brak określenia] [eng]}

W 2010 roku Biblioteka Narodowa przystąpiła do projektu SYNAT (System Nauki i Techniki) zrzeszającego 16 instytucji naukowych z całego kraju. W ramach tego projektu zajmuje się częścią zadania badawczego o nazwie PASSIM. Celem działań konsorcjum jest stworzenie oraz wdrożenie uniwersalnej, otwartej, repozytoryjnej platformy hostingowej i komunikacyjnej dla sieciowych zasobów wiedzy wykorzystywanych przede wszystkim przez badaczy, pracowników nauki, studentów oraz wszystkich tych, którzy dążą do poszerzania wiedzy. Zakład Informacji Naukowej Biblioteki Narodowej odpowiada za identyfikację, systematyzację i ewidencję cyfrowych zasobów informacyjnych zarówno polskich, jak i zagranicznych w zakresie nauk humanistycznych, ekonomicznych i społecznych. W artykule przeanalizowano proces odchodzenia od tradycyjnej formy warsztatu informacyjnego opartego na księgozbiorze podręcznym, kartotekach i katalogach oraz komputerowych bazach danych. Zaprezentowano transformację dokonującą się w sposobie myślenia pracowników ZiNu. Skupiono się przede wszystkim na zagadnieniu przejścia od wykwalifikowanego konsumenta informacji do zaangażowanego w ich tworzenie infobrokera. Omówiono proces powstawania nowej tzw. „bazy baz” integrującej dane dotyczące często także niestandardowych zasobów internetowych, a w szczególności: kryteria selekcji zasobów World Wide Web - problemy i rozwiązania, format zapisu danych jako odzwierciedlenie potrzeb informacyjnych, funkcjonalność bazy — przewidywane ułatwienia i ograniczenia informacyjne.

7. Marek Nahotko, Organizacja wiedzy w umyśle człowieka $w$ świetle teorii schematów i gatunków, „Zagadnienia Informacji Naukowej” 52, 2014, nr 2 (103), s. $80-93$. 
Artykuł w języku polskim FOG Hasłowy 13,31; 4033 słów.

Abstrakt [pol] FOG Hasłowy 16,8; 228 słów.

Słowa kluczowe [pol] liczba słów kluczowych: 6 .

\section{Abstract [eng] \\ Keywords [eng]}

Abstrakt Cel/teza: Celem artykułu jest przedstawienie poglądów na wiedzę jako rezultatu funkcjonowania ludzkiego umysłu, oraz opis zasad i narzędzi organizacji wiedzy w umyśle człowieka, wykorzystywanych do komunikowania wiedzy, m.in. w postaci zapisów informacji (w przypadku wiedzy naukowej - publikacji naukowych). W tym sensie organizacja wiedzy następuje podczas procesów konwersji wiedzy w informację (nadawca) i informacji w wiedzę (odbiorca).

Koncepcja/metody badań: Na podstawie krytycznej analizy piśmiennictwa z zakresu neurologii, psychologii i socjologii, a także językoznawstwa, dokonano opisu procesów mentalnych realizowanych podczas aktywności twórczej, w szczególności związanej z procesami pisania/czytania publikacji naukowych. Uwzględnione zostały w szczególności teorie genploracji, schematów mentalnych i gatunków. Procesy te i aktywności uznane zostały za procesy organizacji wiedzy.

Wyniki i wnioski: W wyniku realizacji mentalnych procesów organizacji wiedzy w mózgu człowieka podczas jego neuronalnej aktywności powstają umysłowe struktury wiedzy, nazywane różnie (schematy, skrypty, ramy, plany) w zależności od teorii opisującej te zjawiska. Podczas aktywności związanych z komunikowaniem się struktury te są z kolei podstawą tworzenia konwencji dotyczących formy i treści przekazywanych informacji w formie tekstowej, zwanych gatunkami. Gatunki, jako konwencje znane i stosowane zarówno przez nadawców, jak i odbiorców komunikatów, ułatwiają konwersje typu informacja — wiedza — informacja (twórczość) i wiedza —informacja - wiedza (komunikacja).

Oryginalność/wartość poznawcza: Artykuł porządkuje wiedzę o procesach organizacji wiedzy, łącząc kilka teorii znanych z neurologii, psychologii i socjologii, co ułatwia właściwe umiejscowienie procesów organizacji wiedzy i stosowanych w niej narzędzi - systemów organizacji wiedzy.

Słowa kluczowe: Gatunki. Genploracja. Organizacja wiedzy. Schematy mentalne. Systemy organizacji wiedzy. Wiedza.

8. Victor N. Nwachukwu, Tony I. Obaseki, Perception of librarians on the use of mobile technologies in meeting information needs of university library patrons, „Przegląd Biblioteczny” 82, 2014, z. 4, s. 537-549 [w jęz. angielskim; tł. tyt.: Technologie mobilne $w$ zaspokajaniu potrzeb informacyjnych użytkowników bibliotek akademickich z punktu widzenia bibliotekarza].

Artykuł w języku angielskim FOG Hasłowy 7,08; 2345 słów.

Keywords [eng] liczba słów kluczowych: 8.

Abstract [eng] FOG Hasłowy 8,01; 240 słów.

Slowa kluczowe [pol]

Abstrakt [pol] 
KEY WORDS: Information age. Globalization. Technological advancement. Information and Communication Technologies. Information Transactions. International collaboration. Marketing. Librarians.

ABSTRACT: Objective - This paper is an in-depth analysis of the theoretical view of librarians with regard to the use of new technologies (such as mobile technologies) for service rendering in libraries in the era of inforrnation age and globalization. It also posits that libraries and librarians in the developing states have a lot to contribute to the socio-economic and infrastructural development of their states. Research method - The paper refers to the changes in the types of Information and Communication Technologies (ICT) available in libraries, and asserts that there is a gradual technological advancement from visible to invisible and from unmovable to movable ICTs. Mobile technologies e.g. iPads, iPods, iPhones, the paper stated have become a part of ordinary life and their common use is overshadowing the existence of computer desktops, and laptops. Mobile technology use is increasing as not only the literate academics use mobile technologies, but also the literate artisans use it for online social networking. The trend this paper asserts is in both societies of the developed and developing states, but buttresses that mobile technologies are judiciously used for information transactions and access to information store-houses in developed states. Thus, the call for librarians to rise up to the task by using mobile technologies for information transaction. Problems of inadequate technical skills, limited bandwidth subscriptions, shortage of technical manpower in libraries, dearth in collaboration, nonchalant attitude of librarians towards novel innovations in libraries, inadequate library marketing programme, under development of library internal online network etc, are rnitigation towards the use of mobile technologies in library service rendering. Results and conclusions - The paper states that collaboration between libraries in the form of an exchange programme between library professionals in developed and developing states, adequate funding of libraries and librarians training, adequate marketing of library facilities and services, and increased lobbying of the government by library heads for better packages for libraries are steps towards ameliorating the problems identified in this paper.

9. Kazimierz Ossowski, Drukarstwo warszawskie w latach 1795-1806, „Roczniki Biblioteczne” 57, 2013, s. 3-44.

Artykuł w języku polskim FOG Hasłowy 10,25; 15704 słów.

[brak określenia] [pol] FOG Hasłowy 6,23; 25 słów.

Słowa kluczowe [pol] liczba słów kluczowych: 4.

Summary [eng]

Keywords [eng]

Drukarnie zlikwidowane. Ostatni drukarze czasów stanisławowskich i ich następcy. Drukarnie zakonne. Drukarnie założone w XIX wieku. Drukarz bez drukarni — przypadek Stefana Baccigalupiego. Drukarnie prasowe. Sztycharnie.

SŁOWA KLUCZOWE: drukarstwo, produkcja wydawnicza, Warszawa, XVIII/XIX wiek

10. Katarzyna Setkowicz, Książka popularna wobec uwarunkowań prawnych i rynkowych hiszpańskiego Złotego Wieku - na przykładzie gatunku libros de caballerías, „Studia o Książce i Informacji” 2013, nr 32, s. 21-29. 
Artykuł w języku polskim FOG Hasłowy 14,26; 3761 słów.

Summary [eng]

11. Arkadiusz Wagner, Poznańskie radełko jagiellońskie z lat czterdziestych XVI wieku. Problem treści ideowo-politycznych $i$ wzorów ikonograficznych, „Roczniki Biblioteczne” 56, 2012, s. 83-111.

Artykuł w języku polskim FOG Hasłowy 11,53; 11441 słów.

[brak określenia] [pol] FOG Hasłowy słów 9,78; 33 słowa.

Słowa kluczowe [pol] liczba słów kluczowych: 12.

Summary [eng]

Keywords [eng]

Poznańskie radełko jagiellońskie jako przedmiot badań. Znane dziś 22 oprawy ozdobione tym radełkiem. Czas oraz miejsce jego powstania i użycia: Poznań, 1547-1560 (hipoteza). Analiza ikonograficzna radełka. Ideologiczne i polityczne źródła ikonografii i radełka.

SŁOWA KLUCZOWE: renesans polski, introligatorstwo, oprawy, radełko jagiellońskie, Zygmunt Stary, Zygmunt August, Paweł III papież, Karol V, Ferdynand I, Jagiellonowie, Habsburgowie, propaganda.

12. Elżbieta Zybert, Współczesne biblioteki więzienne i działalność kulturalno-oświatowa w polskich zakładach Stużby Więziennej, „Przegląd Biblioteczny” 80, 2012, z. 1, s. 3-28.

Artykuł w języku polskim FOG Hasłowy 8,19; 5494 słowa.

Słowa kluczowe [pol] liczba słów kluczowych: 4.

Abstrakt [pol] FOG Hasłowy 9,46; 78 słów.

Keywords [eng]

Abstract [eng]

SŁOWA KLUCZOWE: Biblioteki więzienne. Działalność kulturalno-oświatowa. Służba Więzienna. Polskie zakłady karne.

ABSTRAKT: Cel - W artykule przedstawiono działalność resocjalizacyjną wykorzystującą pracę kulturalno-oświatową, bibliotekę i różne formy przekazu treści, prowadzoną w polskich zakładach penitencjarnych. Głównym celem opracowania było przedstawienie aktualnej sytuacji w bibliotekarstwie więziennym i porównanie jej ze stanem z 1981 r. Metody badań — Dla potrzeb badania zastosowano metodę sondażu diagnostycznego, przeprowadzonego w $2010 \mathrm{r}$. we wszystkich, tj. 156 polskich zakładach penitencjarnych: 86 zakładach karnych i 70 aresztach śledczych. Wyniki i wnioski - Najważniejsze wnioski wynikające z badania wskazują na znaczącą rolę książki i innych materiałów bibliotecznych w działalności resocjalizacyjnej. Nie oznacza to jednak poświęcania szczególnej troski bibliotekom więziennym i doskonalenia ich działalności. Pozytywną zmianą jest wzrost liczby profesjonalnie przygotowanych pracowników Służby Więziennej, którzy nie tylko rozumieją znaczenie książki i działalności kulturalno-oświatowej, ale i w co- 
dziennej pracy organizują przedsięwzięcia popularyzujące czytelnictwo (na przykład wystawy książek, spotkania z autorami, konkursy wiedzy, literackie, czytanie książek przez radiowęzeł), umożliwiają osadzonym udział w kulturze i rozwijanie aktywności twórczych.

\section{ANEKS 2: PROPOZYCJA METODOLOGII WYSELEKCJONOWANIA MATERIAŁU DO DALSZYCH BADAŃ}

Ze względu na ogromny przyrost literatury bibliologicznej na łamach polskich czasopism niemożliwe jest przeprowadzenie badań całości materiału. W związku z tym przed przystąpieniem do prac należy przyjąć pewien zasięg chronologiczny badań (na przykład 1995-2014), a następnie wyselekcjonować w nim reprezentatywną próbę, na której podstawie możliwe będzie uogólnienie wyników na całość możliwego materiału. Selekcja ta powinna być prowadzona w trzech krokach: 1) wybór ty tułów czasopism, 2) ustalenie kryteriów wyboru artykułów w obrębie tytułów, 3) wybór konkretnych artykułów do próby badanej. Badania mogą być prowadzone ogólnie dla bibliologii lub w podziale na przypisanie artykułów do poszczególnych subdyscyplin czy tematów.

1. Wybór tytułów powinno warunkować kilka założeń gwarantujących reprezentatywność grupy. Po pierwsze (a), wychodząc z założenia, że każde polskie czasopismo dbające o renomę ma swoją reprezentację w Internecie, w internetowej bazie informacji o naukowych i branżowych polskich czasopismach elektronicznych Arianta należy wyszukać czasopisma z zakresu bibliologii (reprezentowane tam klasą „bibliotekoznawstwo i informacja naukowa”). Wybór tej bazy jest zasadny, mimo sformułowania użytego w jej nazwie — ,czasopismo elektroniczne": wbrew pozorom za czasopismo elektroniczne uznawane są tam nie tylko te periodyki, które ukazują się w formie elektronicznej, lecz także te, które ukazują się na nośniku fizycznym, ale mają w sieci pełną lub częściową, ale stałą, reprezentację. O doborze tytułów do bazy, według słów Anety Drabek, jej autorki, „decydują względy formalne i merytoryczne. Wśród względów formalnych nieodzowna jest obecność na stronie co najmniej spisów treści" "78. Obecnie trudno wyobrazić sobie bibliologiczne czasopismo papierowe, które nie zamieszcza choćby części informacji o swojej zawartości, toteż można uznać, że wyniki zwrócone przez bazę Arianta (w niniejszym przykładzie: w dniu 31.01.2016 roku) są wynikami pełnymi. W ten sposób w klasie „,bibliotekoznawstwo i informacja naukowa” odnaleziono 83 tytuły czasopism. Ponieważ jednak planowane badania są przewidziane dla artykułów naukowych, listę wyników należy ograniczyć (b) do czasopism stricte naukowych (Arianta gromadzi także informację o czasopismach branżowych), co daje wynik 79 tytułów. Należy uznać, że badając najlepsze jakościowo artykuły,

78 A. Drabek, Arianta i jej rola $w$ upowszechnianiu informacji o polskich czasopismach, „Materiały Konferencyjne EBIB” [czasopismo elektroniczne] 2013, nr 24, s. 2, http://open.ebib.pl/ ojs/index.php/Mat_konf/article/view/25/ [dostęp: 16.01.2019]. 
otrzyma się maksymalne możliwe do uzyskania wyniki w dziedzinie bibliologii, w związku z czym warto wprowadzić kolejne formalne założenie (c), że z puli wszystkich polskich naukowych czasopism bibliologicznych najlepsze jakościowo są te obecne na tzw. liście czasopism punktowanych Ministerstwa Nauki i Szkolnictwa Wyższego aktualizowanej rokrocznie od 2007 roku w komunikacie ministra. To kryterium ograniczy w niniejszym przykładzie listę wyników do 33 tytułów. Po odjęciu z tej listy: czasopism (d), których zakres jest zbyt szeroki (a więc znacznie przekraczający ramy bibliologii w kierunku muzealnictwa, konserwatorstwa, archiwistyki, historii, językoznawstwa, medioznawstwa z prasoznawstwem) lub zbyt wąski (są zbyt specjalistyczne lub nacechowane branżowo), a także tych, które w całości są w języku obcym (na etapie selekcji w obrębie artykułów artykuły w języku obcym powinny być eliminowane, o czym jeszcze niżej); czasopism (e), które pojawiły się na liście pierwszy raz w 2015 roku (przypomnijmy, że zasięg chronologiczny przykładowych badań to lata 1995-2014); czasopism (f), które do roku 2014 pojawiły się na owej liście maksymalnie dwa razy, ostatecznie uzyskujemy listę 15 tytułów, która powinna stanowić podstawę do selekcji stopnia drugiego. Szczegółowe zmiany na liście tytułów predestynowanych do badania przedstawia wykaz 1.

2. W całej puli artykułów pochodzących z owych 15 tytułów należy przeprowadzić dalszą selekcję formalną. Przede wszystkim należy odrzucić wszystkie artykuły niebędące artykułami stricte naukowymi o charakterze oryginalnym lub problemowym. Naukowość można oceniać dwustopniowo: najpierw należy odrzucić wszystkie artykuły umieszczone przez redaktorów w działach innych niż zawierające prace oryginalne (tytułowane zazwyczaj „Studia”, „Badania”, „Problemy”, „Artykuły”, „Rozprawy” itp.), a następnie ocenić, czy faktycznie artykuły zamieszczone w tych działach mają sugerowany charakter. W ten sposób odrzucone zostaną wszelkie artykuły szkoleniowe, odredakcyjne, sprawozdania, recenzje, doniesienia, przyczynki, wspomnienia, wywiady, artykuły jubileuszowe o charakterze honorowym, przeglądy piśmiennictwa, spisy bibliograficzne, informatory, listy, opinie, miscellanea itp. Dodatkowo należy odrzucić te artykuły, w których wybór stylu języka może w dużym stopniu lub w całości nie zależeć od autora tekstu — chodzi między innymi o wszystkie artykuły i materiały źródłowe, reedycje, przedruki, tłumaczenia z literatury obcej. Na końcu należy odrzucić także artykuły spełniające wymienione cechy formalne, ale napisane w języku obcym, ponieważ ze względu na zasadę porównywania porównywalnego nie można porównywać tekstów w różnych językach, gdyż mogłoby to prowadzić do wypaczeń w wynikach z uwagi na różnice gramatyczne i kognitywne tych języków (w badanym dwudziestoleciu takich artykułów było jedynie 39, co stanowi zaledwie 1,51\% wszystkich artykułów). Ostatecznie do dalszej selekcji pozostało 2581 artykułów naukowych o charakterze oryginalnym lub problemowym w języku polskim. Szczegółowe wyniki tej selekcji przedstawiają wykazy 2a i 2b, a statystykę wystąpień tych artykułów ilustruje wykaz 3. 
Wykaz 1. Lista tytułów czasopism z zaznaczeniem kolejnych etapów selekcji

\begin{tabular}{|c|c|c|c|c|c|c|}
\hline lp. & kryterium a & $\mathrm{b}$ & $\mathrm{c}$ & $\mathrm{d}$ & $\mathrm{e}$ & $\mathrm{f}$ \\
\hline 1. & Acta Universitatis Lodziensis. Folia Librorum & + & + & + & + & + \\
\hline 2. & $\begin{array}{l}\text { Acta Universitatis Nicolai Copernici. Nauki Humanistyczno-Spo- } \\
\text { łeczne. Bibliologia }\end{array}$ & + & & & & \\
\hline 3. & Akapit. Rocznik Towarzystwa Bibliofilów Polskich w Warszawie & + & & & & \\
\hline 4. & $\begin{array}{l}\text { Annales Universitatis Paedagogicae Cracoviensis. Studia ad Bi- } \\
\text { bliothecarum Scientiam Pertinentia }\end{array}$ & + & + & + & + & + \\
\hline 5. & Archiwa, Biblioteki i Muzea Kościelne & + & + & & & \\
\hline 6. & Bibliografia Bieżąca Województwa Śląskiego & + & & & & \\
\hline 7. & Bibliografia Historii Kościoła w Polsce & + & & & & \\
\hline 8. & Biblioteka [1960] & + & + & + & + & + \\
\hline 9. & Biblioteka [2008] & & & & & \\
\hline 10. & Biblioteka - Centrum Informacji & + & & & & \\
\hline 11. & Biblioteka i Edukacja & + & + & + & & \\
\hline 12. & Biblioteka w Szkole & + & & & & \\
\hline 13. & Bibliotekarz & + & & & & \\
\hline 14. & Bibliotekarz Lubelski & + & + & + & + & + \\
\hline 15. & Bibliotekarz Lubuski & + & & & & \\
\hline 16. & Bibliotekarz Opolski & + & & & & \\
\hline 17. & Bibliotekarz Płocki & & & & & \\
\hline 18. & Bibliotekarz Podlaski & + & + & + & & \\
\hline 19. & Bibliotekarz Radomski & + & & & & \\
\hline 20. & Bibliotekarz Warmińsko-Mazurski & + & & & & \\
\hline 21. & Bibliotekarz Zachodnio-Pomorski & + & & & & \\
\hline 22. & Bibliotekarz Zamojski & + & & & & \\
\hline 23. & Biblioterapeuta & + & & & & \\
\hline 24. & Bibliotheca Nostra. Śląski Kwartalnik Naukowy & + & + & + & + & \\
\hline 25. & Biuletyn Biblioteki Jagiellońskiej & + & + & + & + & \\
\hline 26. & Biuletyn EBIB & & & & & \\
\hline 27. & $\begin{array}{l}\text { Biuletyn Informacyjny Biblioteki Głównej Uniwersytetu Ekono- } \\
\text { micznego w Krakowie }\end{array}$ & + & & & & \\
\hline 28. & Biuletyn Informacyjny Biblioteki Narodowej & + & & & & \\
\hline 29. & Biuletyn Nauczycieli Bibliotekarzy & + & & & & \\
\hline 30. & Biuletyn Uniwersalnej Klasyfikacji Dziesiętnej & + & & & & \\
\hline 31. & Debiuty Bibliologiczno-Informatologiczne & + & & & & \\
\hline 32. & Dialogi Biblioteczne & + & & & & \\
\hline
\end{tabular}




\begin{tabular}{|c|c|c|c|c|c|c|}
\hline 33. & Dolnośląski Informator Bibliotek Pedagogicznych & + & & & & \\
\hline 34. & Edu-wsparcie & + & & & & \\
\hline 35. & Exempli Gratia & + & & & & \\
\hline 36. & Exlibris & + & & & & \\
\hline 37. & Fibula & + & & & & \\
\hline 38. & Fides. Biuletyn Bibliotek Kościelnych & + & + & + & & \\
\hline 39. & Folia Bibliologica. Biuletyn Biblioteki Głównej UMCS & + & + & + & & \\
\hline 40. & Folia Toruniensia & + & + & + & + & + \\
\hline 41. & Forum Bibliotek Medycznych & + & + & + & + & + \\
\hline 42. & Guliwer & + & + & & & \\
\hline 43. & Hereditas Monasteriorum & + & + & & & \\
\hline 44. & Infotezy & + & & & & \\
\hline 45. & Język, Komunikacja, Informacja & + & + & & & \\
\hline 46. & Krośnieńskie Zeszyty Biblioteczne & + & & & & \\
\hline 47. & Książka i Czytelnik & + & & & & \\
\hline 48. & Notes Biblioteczny [1953] & + & & & & \\
\hline 49. & Notes Biblioteczny [2011] & & & & & \\
\hline 50. & Notes Konserwatorski & + & + & & & \\
\hline 51. & Nowa Biblioteka & + & + & + & + & \\
\hline 52. & Pamiętnik Biblioteki Kórnickiej & + & + & + & & \\
\hline 53. & Podkarpackie Studia Biblioteczne & + & + & + & + & \\
\hline 54. & Polish Libraries & + & + & & & \\
\hline 55. & Polish Libraries Today & + & & & & \\
\hline 56. & Polska Bibliografia Wojskowa & + & & & & \\
\hline 57. & Poradnik Bibliograficzno-Metodyczny & + & & & & \\
\hline 58. & Poradnik Bibliotekarza & + & & & & \\
\hline 59. & Przegląd Biblioteczny & + & + & + & + & + \\
\hline 60. & Przegląd Biblioterapeutyczny & + & + & & & \\
\hline 61. & Przewodnik Bibliograficzny & + & & & & \\
\hline 62. & PTINT Praktyka i Teoria Informacji Naukowej i Technicznej & + & + & + & + & + \\
\hline 63. & Rocznik Bibliologiczno-Prasoznawczy & + & + & + & + & + \\
\hline 64. & Rocznik Biblioteki Głównej Uniwersytetu Opolskiego & + & & & & \\
\hline 65. & Rocznik Biblioteki Narodowej & + & + & + & + & + \\
\hline 66. & Rocznik Biblioteki Naukowej PAU i PAN w Krakowie & + & + & + & & \\
\hline 67. & Rocznik Biblioteki Uniwersyteckiej & + & & & & \\
\hline 68. & Roczniki Biblioteczne & + & + & + & + & + \\
\hline
\end{tabular}




\begin{tabular}{|c|c|c|c|c|c|c|}
\hline 69. & Siglum & + & & & & \\
\hline 70. & Studia Bibliologiczne & + & & & & \\
\hline 71. & $\begin{array}{l}\text { Studia i Materiały Centralnej Biblioteki Wojskowej im. Marszałka } \\
\text { Józefa Piłsudskiego }\end{array}$ & + & & & & \\
\hline 72. & Studia o Książce & + & & & & \\
\hline 73. & Studia o Książce i Informacji & + & + & + & + & + \\
\hline 74. & Studia Sieradzana & + & & & & \\
\hline 75. & Toruńskie Studia Bibliologiczne & + & + & + & + & + \\
\hline 76. & Tytuł Ujednolicony & + & & & & \\
\hline 77. & Uncommon Culture & + & & & & \\
\hline 78. & Warsztaty Bibliotekarskie & + & & & & \\
\hline 79. & Z Badań nad Książką i Księgozbiorami Historycznymi & + & + & + & + & \\
\hline 80. & Zagadnienia Informacji Naukowej & + & + & + & + & + \\
\hline 81. & Zarządzanie Biblioteką & + & + & + & + & + \\
\hline 82. & $\begin{array}{l}\text { Zeszyty Naukowe Wyższej Szkoły Pedagogicznej w Bydgoszczy. } \\
\text { Studia Bibliologiczne }\end{array}$ & + & & & & \\
\hline 83. & Zielonogórskie Studia Bibliotekoznawcze & + & & & & \\
\hline 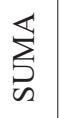 & 83 & 79 & 33 & 26 & 20 & 15 \\
\hline
\end{tabular}

Źródło: opracowanie własne. 
Wykaz 2a. Lista tytułów czasopism wyselekcjonowanych do badań wraz z ich opisem

\begin{tabular}{|c|c|c|c|c|c|c|c|}
\hline$\dot{\sim}$ & 站 & 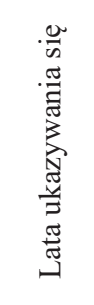 & 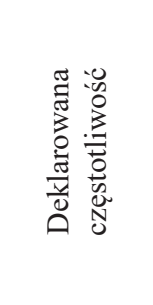 & 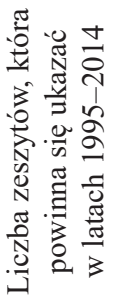 & 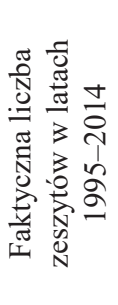 & 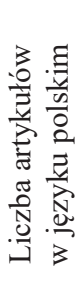 & 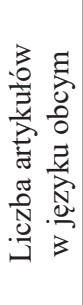 \\
\hline 1. & $\begin{array}{l}\text { Acta Universitatis Lodziensis. } \\
\text { Folia Librorum }\end{array}$ & $1975-$ & $\begin{array}{l}\text { półrocznik } \\
\text { (d. seria) }\end{array}$ & - & 14 & 141 & 1 \\
\hline 2. & $\begin{array}{l}\text { Annales Universitatis Paeda- } \\
\text { gogicae Cracoviensis Studia ad } \\
\text { Bibliothecarum Scientiam Perti- } \\
\text { nentia }\end{array}$ & $1982-$ & $\begin{array}{l}\text { rocznik } \\
\text { (d. seria) }\end{array}$ & - & 14 & 204 & 2 \\
\hline 3. & Biblioteka & $1960-$ & rocznik & 20 & 18 & 182 & 3 \\
\hline 4. & Bibliotekarz Lubelski & $1956-$ & rocznik & 20 & 18 & 122 & 0 \\
\hline 5. & Folia Toruniensia & $2000-$ & rocznik & 15 & 12 & 83 & 0 \\
\hline 6. & Forum Bibliotek Medycznych & $2008-$ & półrocznik & 14 & 14 & 84 & 5 \\
\hline 7. & Przegląd Biblioteczny & $1908-$ & kwartalnik & 80 & 69 & 344 & 4 \\
\hline 8. & $\begin{array}{l}\text { PTINT Praktyka i Teoria Infor- } \\
\text { macji Naukowej i Technicznej }\end{array}$ & $1993-$ & kwartalnik & 80 & 68 & 333 & 0 \\
\hline 9. & $\begin{array}{l}\text { Rocznik Bibliologiczno-Praso- } \\
\text { znawczy }\end{array}$ & $1995-$ & rocznik & 20 & 16 & 157 & 1 \\
\hline 10. & Rocznik Biblioteki Narodowej & $1965-$ & rocznik & 20 & 12 & 200 & 0 \\
\hline 11. & Roczniki Biblioteczne & $1957-$ & rocznik & 20 & 20 & 172 & 0 \\
\hline 12. & Studia o Książce i Informacji & $1966-$ & $\begin{array}{l}\text { rocznik } \\
\text { (d. seria) }\end{array}$ & - & 12 & 130 & 1 \\
\hline 13. & Toruńskie Studia Bibliologiczne & $2008-$ & półrocznik & 13 & 13 & 115 & 3 \\
\hline 14. & $\begin{array}{l}\text { Zagadnienia Informacji Nauko- } \\
\text { wej }\end{array}$ & $1972-$ & półrocznik & 40 & 39 & 260 & 7 \\
\hline \multirow[t]{2}{*}{15.} & Zarządzanie Biblioteką & 2009 & rocznik & 6 & 6 & 54 & 12 \\
\hline & SUMA & $*$ & $*$ & $*$ & 345 & 2581 & 39 \\
\hline
\end{tabular}

Źródło: opracowanie własne. 


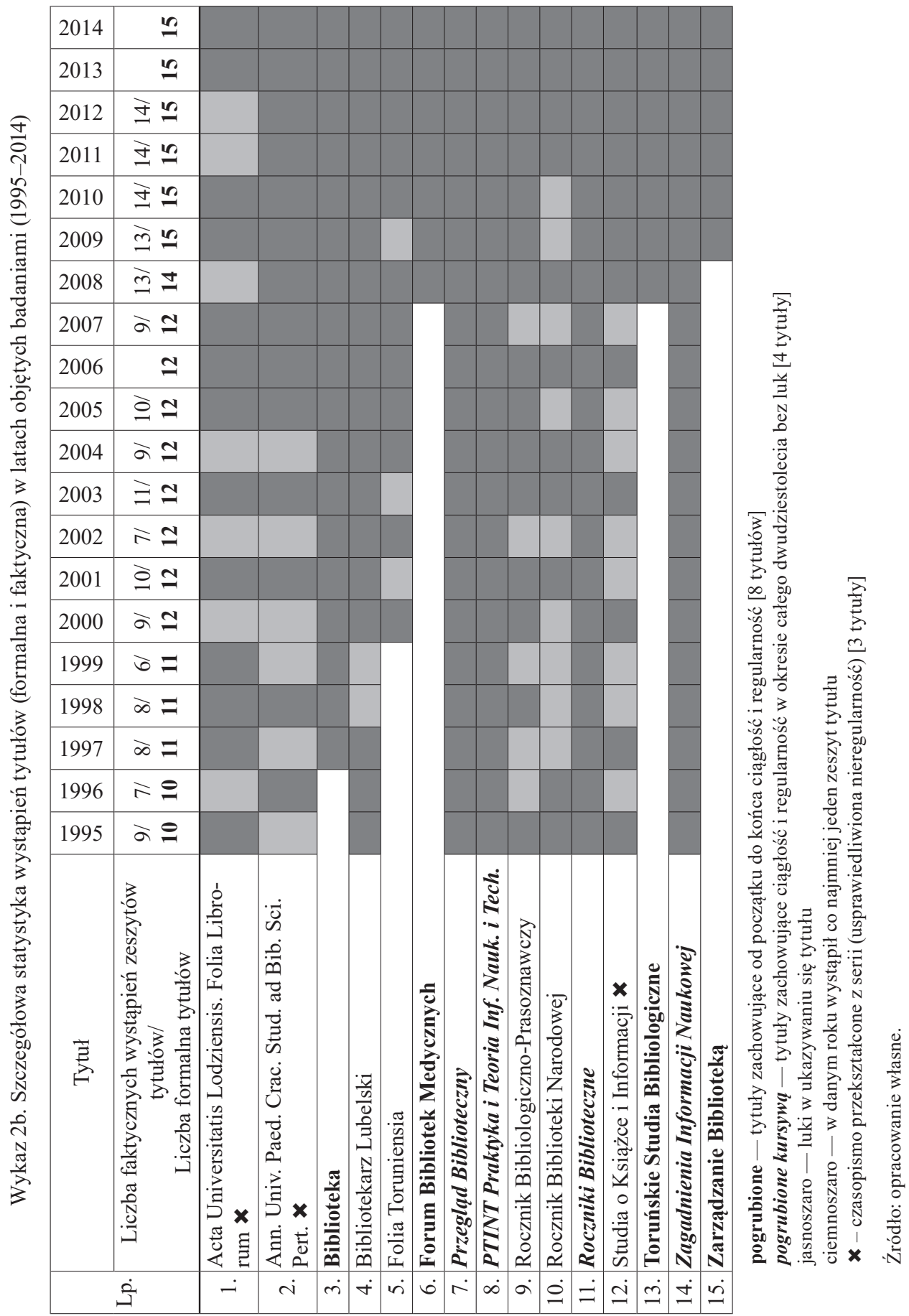




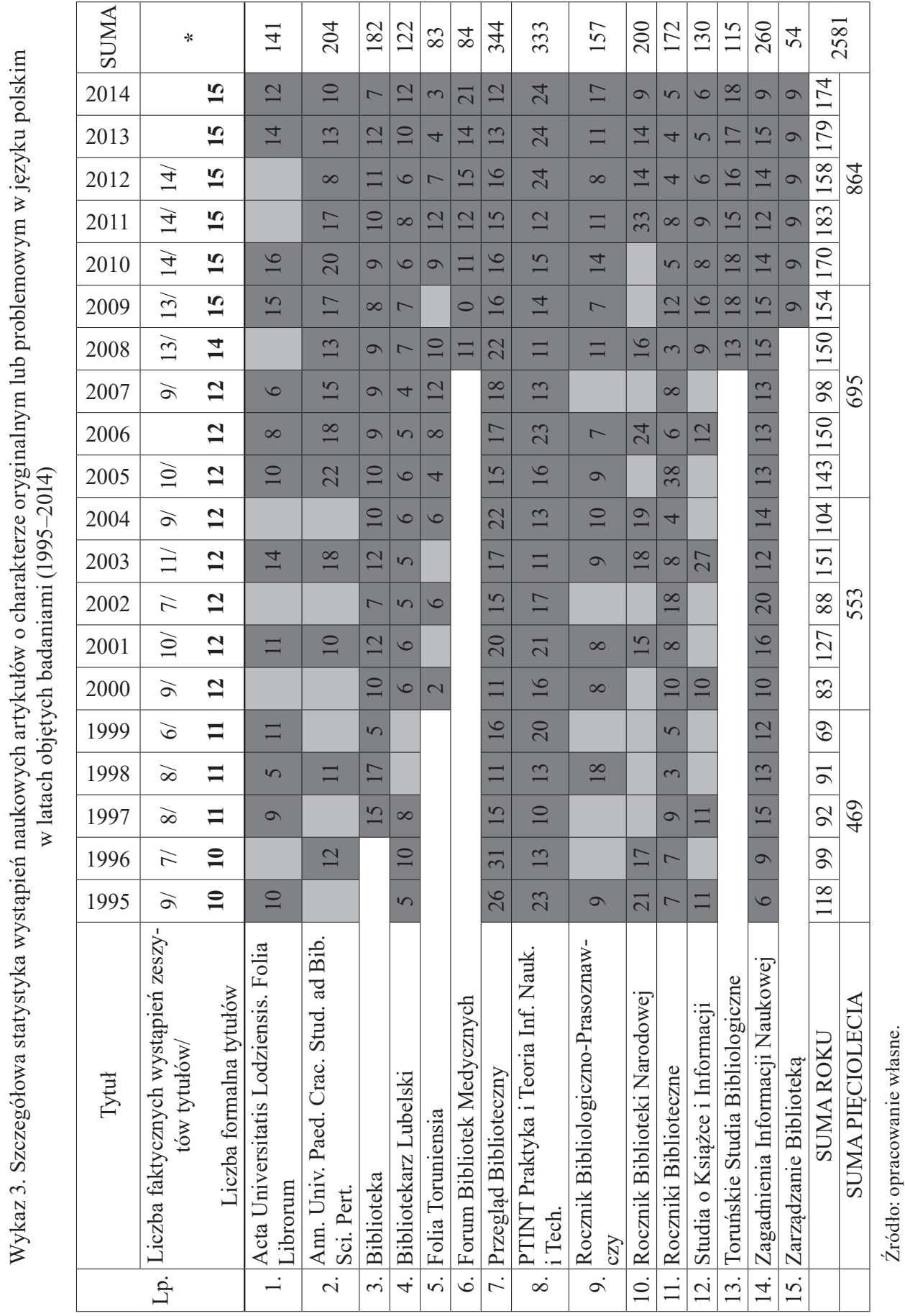




\section{BIBLIOGRAFIA}

Babik W., Ekologia informacji, Kraków 2014.

Babik W., Ekologia informacji - wyzwanie XXI wieku, „Praktyka i Teoria Informacji Naukowej i Technicznej" 10, 2002, z. 1 (37), s. 20-25.

Bielecka-Prus J., Horolets A., Rekonstrukcja praktyk analizy dyskursu na podstawie wybranych anglojęzycznych czasopism dyskursywnych, „Przegląd Socjologii Jakościowej” 9, 2013, z. 1, s. $152-185$.

Dębowski Ł., Analiza statystyczna trudności tekstu, http://jasnopis.pl/static/pdf/seminarium2-jak-wylicza.pdf.

Drabek A., Arianta i jej rola w upowszechnianiu informacji o polskich czasopismach, „Materiały Konferencyjne EBIB" [czasopismo elektroniczne] 2013, nr 24, http:/open.ebib.pl/ojs/index. php/Mat_konf/article/view/25/.

Dronberger G.B., Kowitz G.T., Abstract readability as a factor in information systems, ,Journal of the American Society for Information Science" 26, 1975, z. 2, s. 108-111.

Duszak A., Tekst, dyskurs, komunikacja kulturowa, Warszawa 1998.

EASE Guidelines for authors and translators of scientific articles to be published in English [polska wersja językowa; tłum. S. Ufnalska], 2015, s. 2, http://www.ease.org.uk/sites/default/files/ ease_guidelines-2015-polish.pdf.

Encyklopedia wiedzy o książe, pod red. A. Birkenmajera, B. Kocowskiego, J. Trzynadlowskiego, Wrocław 1971.

Goban-Klas T., Sienkiewicz P., Społeczeństwo informacyjne. Szanse, zagrożenia, wyzwania, Kraków 1999.

Gruszczyński W., Jak powstawat Jasnopis, http://www.jasnopis.pl/static/pdf/seminarium2-jak-powstawal.pdf.

Gruszczyński W., Broda B., Nitoń B., Ogrodniczuk M., W poszukiwaniu metody automatycznego mierzenia zrozumiałości tekstów informacyjnych, „Poradnik Językowy” 2015, nr 2, s. 9-22.

Gunning R., The Technique of Clear Writing, New York 1952.

Hartley J., Current findings from research on structured abstracts, „, Journal of the Medical Library Association" 92, 2004, z. 3, s. 368-371.

Hartley J., Improving the clarity of journal abstracts in psychology. The case for structure, „Science Communication" 24, 2003, z. 3, s. 366-379.

Jasnopis, czyli mierzenie zrozumiałości polskich tekstów użytkowych, pod red. W. Gruszczyńskiego, M. Ogrodniczuka, Warszawa 2015.

King R., A comparison of the readability of abstracts with their source documents, „Journal of the American Society for Information Science" 27, 1976, z. 2, s. 118-121.

Matczuk A., Adnotacja, [hasło w:] Encyklopedia ksiązki, t. 1, pod red. A. Żbikowskiej-Migoń, M. Skalskiej-Zlat, Wrocław 2017, s. 144-145.

Niementowski S.J., Propozycja zmian w PN-77/N-01221 Adnotacje i analizy dokumentacyjne. Artykut dyskusyjny, „Normalizacja” 60, 1992, z. 6, s. 32-33.

Norma PN-N-01221:1977 Adnotacje i analizy dokumentacyjne.

Norma ISO 214:1976 Documentation - Abstracts for publications and documentation.

Norma PN-ISO 5127:2005 Informacja i dokumentacja. Terminologia.

$O T S B$, http://www.home.umk.pl/ tsb/?q=pl/ [dostęp: 16.01.2016].

Perswazja, [hasło w:] Słownik języka polskiego PWN, http://sjp.pwn.pl/sjp/perswazja;2571293 [dostęp: 17.10.2018].

Piekot T., Zarzeczny G., Jak napisać efektywny abstrakt - efektywna kompozycja, ,Przegląd Uniwersytecki” 21, 2015, z. 2 (207), s. 31-33. 
Piekot T., Zarzeczny G., Jak napisać efektywny abstrakt? Część pierwsza, „Przegląd Uniwersytecki” 20, 2014, z. 2 (203), s. 31-33.

Piekot T., Zarzeczny G., Jak zwiększyć efektywność abstraktu za pomoca kilku kropek, „Przegląd Uniwersytecki” 20, 2014, z. 4 (205), s. 30-32.

Pisarek W., Jak mierzyć zrozumiałość tekstu?, „Zeszyty Prasoznawcze” 10, 1969, nr 4, s. 35-48.

Podręczny słownik bibliotekarza, oprac. G. Czapnik, Z. Gruszka przy współpr. H. Tadeusiewicz, Warszawa 2011.

Praktyka i Teoria Informacji Naukowej i Technicznej, http://www.ptin.org.pl/ptint.html [dostęp: 17.10.2018].

Price D.J. de Solla, Little science — big science, New York 1963 [wyd. polskie: Mała nauka — wielka nauka, Warszawa 1967].

Price D.J. de Solla, Science since Babylon, New Haven 1961 [wyd. polskie w: Price Derek John de Solla, Węzlowe problemy historii nauki, Warszawa 1965, s. 94-121].

Przegląd Biblioteczny, http://www.sbp.pl/przeglad [dostęp: 17.10.2018].

Publication Manual of the American Psychological Association, Washington 2001.

Roczniki Biblioteczne. Ogólnopolskie czasopismo naukowe z zakresu nauki o książce i bibliotekoznawstwa, http://rocznikibiblioteczne.ibi.uni.wroc.pl/ [dostęp: 17.10.2018].

Stownik encyklopedyczny informacji, języków i systemów informacyjno-wyszukiwawczych, oprac. B. Bojar, Warszawa 2002.

Sosińska-Kalata B., Abstrakt, [hasło w:] Encyklopedia książki, t. 1, pod red. A. Żbikowskiej-Migoń, M. Skalskiej-Zlat, Wrocław 2017, s. 141-143.

Studia o Książce i Informacji (dawniej: Bibliotekoznawstwo), http://bibl.sjol.eu/ [dostęp: 17.10.2018]. Tadeusiewicz R., Spoteczność internetu, Warszawa 2002.

Wheatley A., Armstrong C.J., A survey of the content and characteristics of electronic abstracts, 1997, http://www.ukoln.ac.uk/services/elib/papers/supporting/pdf/abstracts.pdf.

Wielka encyklopedia PWN, t. 1-30, pod red. J. Wojnowskiego, Warszawa 2001-2005.

Wojtak M., Dyskurs asekuracyjny w dyskursie naukowym, [w:] Dyskurs naukowy - tradycja i zmia$n a$, pod red. S. Gajdy, Opole 1999, s. 139-146.

Zagadnienia Informacji Naukowej - Studia Informacyjne, http://www.sbp.pl/artykul/?cid= 2885\&prev=497 [dostęp: 17.10.2018].

KATARZYNA JAMROZIK, JAKUB MACIEJ ŁUBOCKI

THEORETICAL ASPECTS OF DOCUMENTARY ELEMENTS (WITH SPECIAL CONSIDERATION OF ABSTRACTS). A RESEARCH PROPOSAL CONCERNING ARTICLES FROM BIBLIOLOGY JOURNALS

\section{Summary}

Referring to the changes taking place in modern scholarly communication and the specificity of scholarly discourse, the authors present the latest conclusions from research concerning improvement of comprehensibility of documentary analyses, summaries and abstracts. This is influenced by text readability, and the structure and cognitive value of documentary elements. The authors present a typology of such elements as well as their distinctive features. On this basis they propose a new research methodology. Thanks to this methodology it will be possible to verify: 1. whether elements attached to articles from bibliology journals are, according to recommendations, more readable (easier to comprehend) than the content of the articles themselves; 
2. the current tendency in their length, which should be increased, according to recommendations; 3. whether, in accordance with recommendations, all key words have been used in the elements, which will facilitate article indexation in databases; 4 . whether the existing terminological recommendations correspond to the actual language usage. The initial results obtained by the authors show that research in this area should be continued, as the proposed hypotheses require in-depth analysis and verification.

KEY WORDS: documentary analyses, abstracts, structural abstracts, readability 